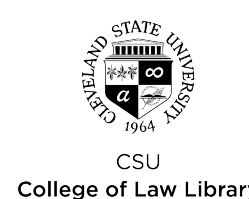

Cleveland State Law Review

Volume 65 | Issue 3

Article

6-1-2017

\title{
Punitive Damages Revisited: A Statistical Analysis of How Federal Circuit Courts Decide the Constitutionality of Such Awards
}

Hironari Momioka

Hokkaido University of Education

Follow this and additional works at: https://engagedscholarship.csuohio.edu/clevstlrev

Part of the Civil Law Commons, Fourteenth Amendment Commons, Supreme Court of the United States Commons, and the Torts Commons

How does access to this work benefit you? Let us know!

\section{Recommended Citation}

Hironari Momioka, Punitive Damages Revisited: A Statistical Analysis of How Federal Circuit Courts Decide the Constitutionality of Such Awards, 65 Clev. St. L. Rev. 379 (2017) available at https://engagedscholarship.csuohio.edu/clevstlrev/vol65/iss3/7

This Article is brought to you for free and open access by the Journals at EngagedScholarship@CSU. It has been accepted for inclusion in Cleveland State Law Review by an authorized editor of EngagedScholarship@CSU. For more information, please contact library.es@csuohio.edu. 


\title{
PUNITIVE DAMAGES REVISITED: A STATISTICAL ANALYSIS OF HOW FEDERAL CIRCUIT COURTS DECIDE THE CONSTITUTIONALITY OF SUCH AWARDS
}

\author{
HIRONARI MOMIOKA* \\ "It is of great use to the sailor to know the length of his line, though he cannot with \\ it fathom all the depths of the ocean." \\ -John Locke \\ ABSTRACT
}

Using data from punitive damages decisions of U.S. federal circuit courts from 2004 to 2012, this paper attempts to establish empirically the following: (1) there is no apparent statistical difference between the levels of jury and judge awards; (2) U.S. Supreme Court decisions such as Philip Morris (2007) or Exxon (2008) do not actually or substantially affect the level of punitive damage awards; (3) with regard to the cases involving remittitur, or reduction of awards, the Exxon decision did not radically affect the decreasing ratio of punitive to compensatory damage awards; (4) as the levels of compensatory awards go up, the ratio becomes strikingly low and stable; (5) finally, the proportionality between punitive and compensatory awards is not the key factor that influences upper court judges when they consider the constitutionality of punitive damages. Unexplained portions of the relationship between the amount of punitive damages and the wealth of a defendant remain to be examined further.

\section{CONTENTS}

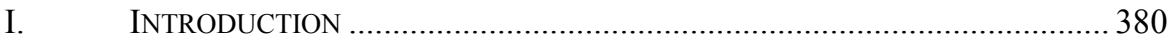

II. CASES OF PUnitive DAMAgeS: A SUMmarY ......................................... 384

A. The Pre-BMW of North America, Inc. v Gore Period: Punitive Damage Awards Not Constitutionally Limited....

B. BMW of North America v. Gore (1996) and its Aftermath: Punitive Damages Awards Constitutionally Limited ................................. 386

C. $\quad$ State Farm (2003): Single Digit Rule .............................................. 387

D. Philip Morris (2007): Procedural Due Process............................. 388

E. Exxon (2008): One to One Ratio Rule ............................................ 389

F. This Article's Contribution to an Understanding of Punitive Damages

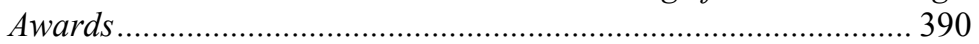

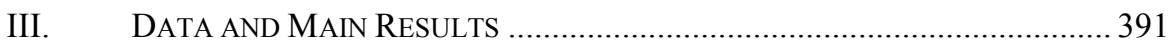

A. The Data Used in This Study ..................................................... 391

B. The Punitive to Compensatory Damages Ratio .............................. 391

C. Judge-Jury Differences................................................................... 392

D. Case Category, Case Types, Party Status, and Locale.................. 394

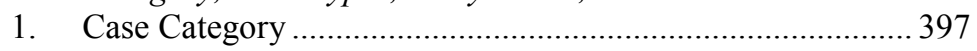

* Professor, Asahikawa Campus, Hokkaido University of Education, Japan. 
2. Litigant Type 397

E. The Supreme Court Decisions and Circuit Court Judges.............. 398

1. Punitive Damages over Time: Ratio by Year..........................398

2. Punitive Damages over Time: Ratio by Period ...................... 399

3. Reduced Damages (Remittitur)........................................... 401

F. $\quad$ Stratifying the Punitive to Compensatory Ratio ........................... 403

G. Federal Circuit Court and Punitive Damages.............................. 405

1. Federal Circuit Court Judges' Decisions to Affirm or Deny Awarded Punitive Damages................................................... 405

2. Logistic Regression Models of Whether or Not Awarded Punitive Damages Were Affirmed ........................................... 406

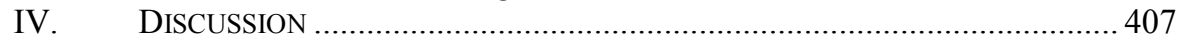

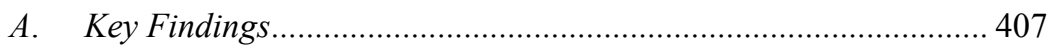

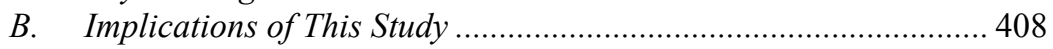

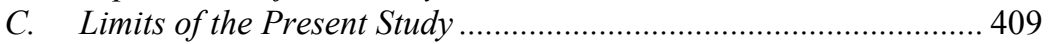

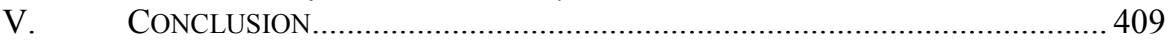

\section{INTRODUCTION}

Punitive damages have become an increasingly controversial subject, in both scholarly and legislative debate, over the past three decades in the United States. One of the reasons why punitive damages are hotly debated in U.S. tort reform debates is that punitive damages award amounts can be quite large-even astronomical. One illustration is the Supreme Court's 2007 Philip Morris USA v. Williams decision. ${ }^{1}$ In this case, a jury in Oregon awarded the plaintiff (the widow of a heavy smoker) $\$ 79.5$ million in punitive damages at trial. ${ }^{2}$ In that regard, civil jury trials and punitive damages in general are, more often than not, a target of audible public criticism, inter alia from tort reformers.

By no means are debates regarding punitive damage awards limited to the United States. Punitive damage awards are also a source of tension in international civil justice relations. For example, the Supreme Court of Japan dealt with a civil case in 1997 where one of the legal issues was whether punitive damages, awarded by a California court, could be compulsorily required through civil procedure in Japan. ${ }^{3}$ The Court refused to order the defendant to pay punitive damages on the grounds that such awards went against public policy in Japan. ${ }^{4}$ One might say, however, that the raison d'être of-or public policy reasons behind-punitive damage awards seem underappreciated by the Japanese Court.

In Japanese legal academic circles, much lengthy attention has been paid to the punitive awards system from the viewpoint of punishing or deterring defendants'

1 Philip Morris USA v. Williams, 549 U.S. 346 (2007).

2 Id. at 350.

3 For a full account of this case, see Norman T. Braslow, The Recognition and Enforcement of Common Law Punitive Damages in a Civil Law System: Some Reflections on the Japanese Experience, 16 ARIZ. J. INT'L \& COMP. LAW 285, 288-99 (1999).

4 See John Y. Gotanda, Charting Developments Concerning Punitive Damages: Is the Tide Changing?, 45 Colum. J. Transnat'L L. 507, 514, 518, 528 (2007) (stating refusals to enforce judgments by Japanese, Italian, and German courts). 
wrongdoing via civil lawsuits. ${ }^{5}$ That is partly because Japan's legal system has neither punitive damages nor jury trials in the civil system and partly because the public law system, which includes criminal and administrative proceedings, does not necessarily function so effectively as to punish or deter a huge corporation's wrongdoings. ${ }^{6}$ In sum, punitive damages awards are alien to the Japanese legal system, but the heated controversy over such awards is nonetheless of great interest to a host of jurists in Japan. ${ }^{7}$

In order to cope with these issues, the U.S. Supreme Court has repeatedly attempted to stop or prevent punitive awards from "running wild" or "skyrocketing" by suggesting that the Due Process Clauses of the U.S. Constitution limit the punitive damages regime. ${ }^{8}$ Specifically, the U.S. Supreme Court held that: (1) punitive damages could violate the substantive due process of law if they are "grossly excessive" in BMW of North America, Inc. v. Gore, ${ }^{9}$ (2) a single digit punitive-to-compensatory damages ratio is more likely to comport with due process in State Farm Auto. Ins. v. Campbell, ${ }^{10}$ (3) the jury shall not take into consideration the harm that the misconduct caused others when calculating the punitive damages in Philip Morris USA v. Williams, ${ }^{11}$ and (4) under maritime law, the ratio shall not exceed one in Exxon Shipping v. Baker. ${ }^{12}$

In parallel with the U.S. Supreme Court's intense attempts to prevent punitive awards from "skyrocketing," quite a few states have passed legislation imposing various limits on punitive awards over the course of the last two decades. There are several types of statutory regulations: ${ }^{13}$ absolute monetary caps,${ }^{14}$ maximum ratio of punitive to compensatory awards, ${ }^{15}$ and a combination of the two.${ }^{16}$ In addition, there

5 Saisiri Siriviriyakul, The Imposition of Punitive Damages: A Comparative Analysis 50 (2012) (on file with the Univ. of Ill. at Urbana-Champaign).

6 Jeffrey Hays, Legal System in Japan-History, Judges, Lawyers, Long Trials,

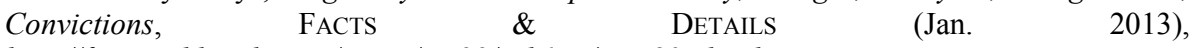
http://factsanddetails.com/japan/cat22/sub147/item807.html.

7 See, e.g., Hisashi Aizawa et al., Recent Developments in Punitive Damages Laws, 72 Comp. L. J. 110, 110-35, 216-18 (2011) (summary in English).

8 Pac. Mut. Life Ins. Co. v. Haslip, 499 U.S. 1, 18 (1991).

9 BMW of North Am., Inc. v. Gore, 517 U.S. 559, 562 (1996). For more details, see infra Section II.B and accompanying text.

10 State Farm Mut. Aut. Ins. Co. v. Campbell, 538 U.S. 408, 425 (2003). For more details, see infra Section II.C and accompanying text.

11 Phillip Morris USA v. Williams, 549 U.S. 346, 355 (2007). For more details, see infra Section II.D and accompanying text.

12 Exxon Shipping Co. v. Baker, 554 U.S. 471, 513 (2008). For more details, see infra Section II.E and accompanying text.

13 See generally John J. Kircher \& Christine M. Wiseman, Punitive Damages: LaW AND PRACTiCE 487-525 ( $2 \mathrm{~d}$ ed. 2012).

14 The Virginia statute, for example, limits the total amount of punitive damages to $\$ 350,000$. VA. CODE ANN. § 8.01-38.1 (2016). Similarly, the Georgia statute limits the amount of such damages to $\$ 250,000$. GA. CODE ANN. § 51-12-5.1(g) (2016).

15 The State of Colorado has limited the amount of punitive damages to the amount of actual damages. Colo. Rev. StAT. § 13-21-102(2) (2016). 
are several other ways that courts have exercised greater judicial control over punitive awards, including lifting the burden of proof, ${ }^{17}$ ordering payment to a state fund, ${ }^{18}$ requiring the plaintiff to prove the defendant's wealth, ${ }^{19}$ bifurcation of trials, ${ }^{20}$ and judicial determination of the punitive damage amount. ${ }^{21}$

On the other hand, the underlying debate over the unpredictability of punitive awards still simmers in legal academic circles. A considerable number of statistical studies have been conducted on the punitive damages system. ${ }^{22}$ Through those

16 A number of states have adopted this type of restriction. Florida, for example, has limited any punitive damage recovery to three times the amount of compensatory damages awarded or $\$ 500,000$, whichever is greater. FlA. STAT. § 768.73(1)(a) (2016). Likewise, in South Carolina, three times, \$500,000, S.C. CoDE ANN. § 15-32-530(A) (2016); Tennessee, two times, \$500,000, TENN. CODE ANN. § 29-39-104(a)(5) (2016); and Arkansas, three times, $\$ 250,000$, ARK. CODE ANN. § 16-55-208(a)(1) (2016). Another version of a limitation includes the wealth of the defendant: a Montana statute provides that an award for punitive damages may not exceed $\$ 10$ million or 3\% of a defendant's net worth, whichever is less. MONT. CODE ANN. § 27-1-220(3) (2015).

17 To date, Colorado is the only jurisdiction that has lifted the burden of proof to "beyond a reasonable doubt," instead of "clear and convincing proof" or "preponderance of evidence." Colo. Rev. Stat. § 13-25-127(2) (2016).

18 Several states have enacted legislation authorizing distribution of some portion of the punitive damages to a state or public entity. In Georgia, for example, $75 \%$ of any amounts awarded as punitive or exemplary damages must be paid into the treasury of the state. GA. CODE. ANN. § 51-12-5.1(e)(2) (2016); see also Mack Trucks, Inc. v. Conkle, 263 Ga. 539, 542 (1993).

19 Several jurisdictions have limited the introduction of evidence regarding the defendant's wealth when a claim for punitive damages is made, so that the fact finder can concentrate on the defendant's conduct rather than on her or his "wealth." Florida, for example, allows no discovery of the defendant's financial worth "unless there is a reasonable showing . . . for recovery of [punitive] damages." Fla. STAT. ANN. § 768.72 (2016). These changes represent legislative attempts to minimize the prejudicial effects of otherwise relevant evidence in punitive damages litigation.

20 Several jurisdictions provide by statute that the trial must be bifurcated to separate punitive damage claim from the underlying liability issues including compensatory damages. For example, Georgia, Montana, and Nevada require bifurcation in all punitive damage cases. Ga. Code AnN. § 51-12-5.1(d) (2016); Mont. Code AnN. § 27-1-221(7) (2015); Nev. Rev. STAT. § 42.005(3) (2015).

21 A few states, including Kansas, have enacted legislation requiring the court, rather than the jury, to determine the amount of any punitive damage award. KAN. STAT. ANN. § 603701(a) (2016).

22 See, e.g., Theodore Eisenberg \& Michael Heise, Judge-Jury Difference in Punitive Damages Awards: Who Listens to the Supreme Court?, 8 J. EMPIRICAL Legal Stud. 325 (2011) [hereinafter Eisenberg \& Heise, Judge-Jury Difference]; Theodore Eisenberg et al., The Decision to Award Punitive Damages: An Empirical Study, 2 J. L. Anal. 577 (2010) [hereinafter Eisenberg et al., Empirical Study]; Theodore Eisenberg et al., Variability in Punitive Damages: Empirically Assessing Exxon Shipping Co. v. Baker, 166 J. Inst. \& Theoretical ECon. 5 (2010) [hereinafter Eisenberg et al., Variability in Punitive Damages]; Neil Vidmar \& Mirya Holman, The Frequency, Predictability, and Proportionality of Jury Awards of Punitive Damages in State Courts in 2005: A New Audit, 43 Suffolk U. L. Rev. 855 (2010); Theodore Eisenberg \& Martin T. Wells, The Significant Association Between 
empirical studies, including those conducted by Cornell Law Professor Theodore Eisenberg, there is a recognition that punitive damages are rarely awarded and the amount assessed by the jury is lower than originally imagined. ${ }^{23}$ Conversely, some critics, including Harvard Law Professor W. Kip Viscusi, argue that punitive awards resulting from jury trials are unpredictable and that "juries are especially likely to make a large punitive damages award" in comparison to judges. ${ }^{24}$

There have been, however, no full-fledged empirical or statistical studies that examine the relationship between the Supreme Court's position on the constitutionality of punitive damages and the behavior of lower courts involving punitive awards claims. In other words, notwithstanding its extreme importance, very few attempts have been made to explain how the Supreme Court decisions have influenced the lower courts within the scheme of punitive damages. ${ }^{25}$

This raises an interesting underlying question: Does the punitive damages award regime operate to punish or deter wrongful acts, or does the award serve the American public in some other way? How and to what extent punitive damages function in American society is of great interest. According to Justice Holmes, the law does not exist in a vacuum, but responds to "felt needs of society" ${ }^{26}$ Law and the system that enforces it, such as the civil jury procedure, case law, and so on, have close relations to the society to which they belong. Ubi societas, ibi ius, as the Roman legal maxim goes. ${ }^{27}$ It is undoubtedly a crux of the debate over the punitive damages system.

At the same time, it is extremely hard and almost impossible to prove or find evidence of the link between laws. Therefore, as a preliminary and exploratory study, this article will explore the connection between the U.S. Supreme Court decisions mentioned above and lower courts decisions, with respect to punitive damages awarded.

Specifically, this article examines the impact of major U.S. Supreme Court decisions regarding punitive damages, such as Philip Morris and Exxon, on lower courts. This article gathers and analyzes data spanning eight years (2004-2012) from federal circuit court decisions. Considering this new data set will augment analysis contained in previous studies by providing more detailed and nuanced insight.

Punitive and Compensatory Damages in Blockbuster Cases: A Methodological Primer, 3 J. EMPIRICAL L. STUD. 175 (2006).

23 See, e.g., Eisenberg et al., Empirical Study, supra note 22, at 578-89.

24 See, e.g., Joni Hersch \& W. Kip Viscusi, Punitive Damages: How Judges and Juries Perform, 33 J. Legal Stud. 1, 36 (2004) [hereinafter Hersch \& Viscusi, Perform]; see also W. Kip Viscusi, The Challenge of Punitive Damages Mathematics, 30 J. Legal Stud. 313, 342 (2001) (stating that jurors informed with a detailed rationale and mathematical formula for setting punitive damages would not perform well).

25 See Greg Sobolski \& Matt Steinberg, An Empirical Analysis of Section 1983 Qualified Immunity Actions and Implications of Pearson v. Callahan, 62 STAN. L. Rev. 523 (2010).

26 Michael C. Lasky, Recent Developments in Employment Law, FindLAw, http://corporate.findlaw.com/litigation-disputes/recent-developments-in-employment-law.html (last visited Jan. 29, 2017).

27 Frank J. Garcia, Between Cosmopolis and Community: The Emerging Basis for Global Justice, 46 N.Y.U. J. INT'L L. \& POL. 1, 1 n.1 (2013). The Roman legal maxim translates to, "Where there is society, there are laws." Id. 
Furthermore, this article attempts to examine both whether the ratio of punitive to compensatory damages significantly differs across different levels of compensatory damages and what kind of factors appellate judges consider most frequently when deciding the validity or adequacy of punitive awards, from the perspective of substantive due process. This study utilizes a statistical approach. ${ }^{28}$

Section II begins with an examination of U.S. Supreme Court decisions dealing with the issue of punitive damages. Section III elaborates on the descriptive results of the analysis, using several statistical techniques. Section IV discusses the results, and Section $\mathrm{V}$ provides a conclusion.

\section{CASES OF Punitive Damages: A Summary}

The punitive damages system is well established in American tort law. For more than two decades, however, the U.S. Supreme Court has amended the punitive damages regime in quite a few decisions, resulting in important constitutional restrictions on such awards. These decisions include: Browning-Ferris Industries of Vermont, Inc. v. Kelco Disposal, Inc., ${ }^{29}$ Pacific Mutual Life Insurance Co. v. Haslip, ${ }^{30}$ TXO Production Corp. v. Alliance Resources Corp., ${ }^{31}$ BMW of North America Inc. v. Gore, ${ }^{32}$ State Farm Mutual Automobile Insurance Co. v. Campbell, ${ }^{33}$ Philip Morris USA v. Williams, ${ }^{34}$ and Exxon Shipping Co. v. Baker. ${ }^{35}$

28 Adopting this kind of "statistical" or "empirical" approach to a legal phenomenon is less common, prevalent, or widely used in America, even less so in Japan. However, an empirical approach is essential and valuable because every single legal doctrine shall be based upon a precise grasp of status quo. I firmly believe so precisely because I have obtained corroborative evidence that data results correctly gathered and analyzed are of great use and importance because of my previous work concerning an attitudinal survey on indigenous people's civil rights in Hokkaido, Japan. See Hironari Momioka, Taking Minority Rights Seriously: A Statistical Analysis of the Attitude Survey of Ainu Culture Law, part 2, 58 (2) J. Hokkaido U. Educ. 17 (2008); Hironari Momioka, Civil Rights and the Courts: A Statistical Analysis of the Attitude Survey of The Nibutani Dam Decision and Ainu Culture Law, 113 (5 \& 6) Chuo L. Rev. 33 (2007). Furthermore, in the future, I will extend the methodology employed in this project to examining areas such as judicial review, freedom of the press, and equal protection of the law. Specifically, I expect that logistic regression models can be applied to an analysis of judicial review.

29 Browning-Ferris Indus. of Vermont, Inc. v. Kelco Disposal, Inc., 492 U.S. 257, 259 (1989).

30 Pac. Mut. Life Ins. Co. v. Haslip, 499 U.S. 1, 4 (1991).

31 TXO Prod. Corp. v. All. Res. Corp., 509 U.S. 443, 446 (1993).

32 BMW of N. Am., Inc. v. Gore, 517 U.S. 559, 562-63 (1996).

33 State Farm Mut. Auto Ins. Co. v. Campbell, 538 U.S. 408, 412 (2003).

34 Phillip Morris USA v. Williams, 549 U.S. 346, 349 (2007).

35 Exxon Shipping Co. v. Baker, 554 U.S. 471, $475-76$ (2008). There are other Supreme Court decisions, such as Cooper Indus., Inc. v. Leatherman Tool Grp., Inc., 532 U.S. 424, 443 (2001) (observing that de novo standard, instead of abuse of discretion standard, is required when the federal appeal courts examine punitive awards); Honda Motor Co. v. Oberg, 512 U.S. 415, 418 (1994) (stating that a state constitutional provision limiting judicial review of the size of punitive damage awards was in violation of the Due Process of the federal Constitution). 


\section{A. The Pre-BMW of North America, Inc. v Gore Period: Punitive Damage Awards Not Constitutionally Limited}

In Browning-Ferris, the U.S. Supreme Court considered whether a large punitive damages award violates the Eighth Amendment prohibition on "excessive fines." 36 In this case, the defendant attempted to pressure the plaintiff to leave a local disposal business by engaging in illegal price-fixing and interference with contracts. ${ }^{37}$ The jury awarded the plaintiff $\$ 51,146$ in compensatory damages and $\$ 6$ million in punitive damages. ${ }^{38}$ The Court held that the Eighth Amendment did not apply to limit punitive damages in this case because the plaintiff was a non-governmental party. ${ }^{39}$

In the Haslip case, the Court addressed the issue of whether the Fourteenth Amendment applies to punitive damages. ${ }^{40}$ The Court approved the punitive damage award granted at trial, which was more than four times the amount of compensatory damages awarded. ${ }^{41}$ The Court commented that "unlimited jury discretion . . . in the fixing of punitive damages may invite extreme results that jar one's constitutional sensibilities." ${ }^{\prime 2}$ Because the actual jury instructions at issue, however, ensured that the jury's discretion was "exercised within reasonable constraints," ${ }^{3}$ the punitive awards did not violate the due process of the law. ${ }^{44}$

Haslip also contains reference to the goals of punitive damages. ${ }^{45}$ With respect to the specific jury instructions at issue, the Court explained that the very purpose of such awards is not to compensate, but to punish the wrongdoers and "protect the public by [deterring] the defendant and others" 46 from engaging in similar harmful acts in the future. According to the instructions given in Haslip, the Court called upon the jury to take into consideration "the character and the degree of the wrong as shown by the evidence and the necessity of preventing similar wrong." 47 The Court concluded that the states' appellate review of such awards also limited the jury's discretion. ${ }^{48}$

36 Browning-Ferris Indus. of Vermont, Inc. v. Kelco Disposal, Inc., 492 U.S. 257, 260 (1989).

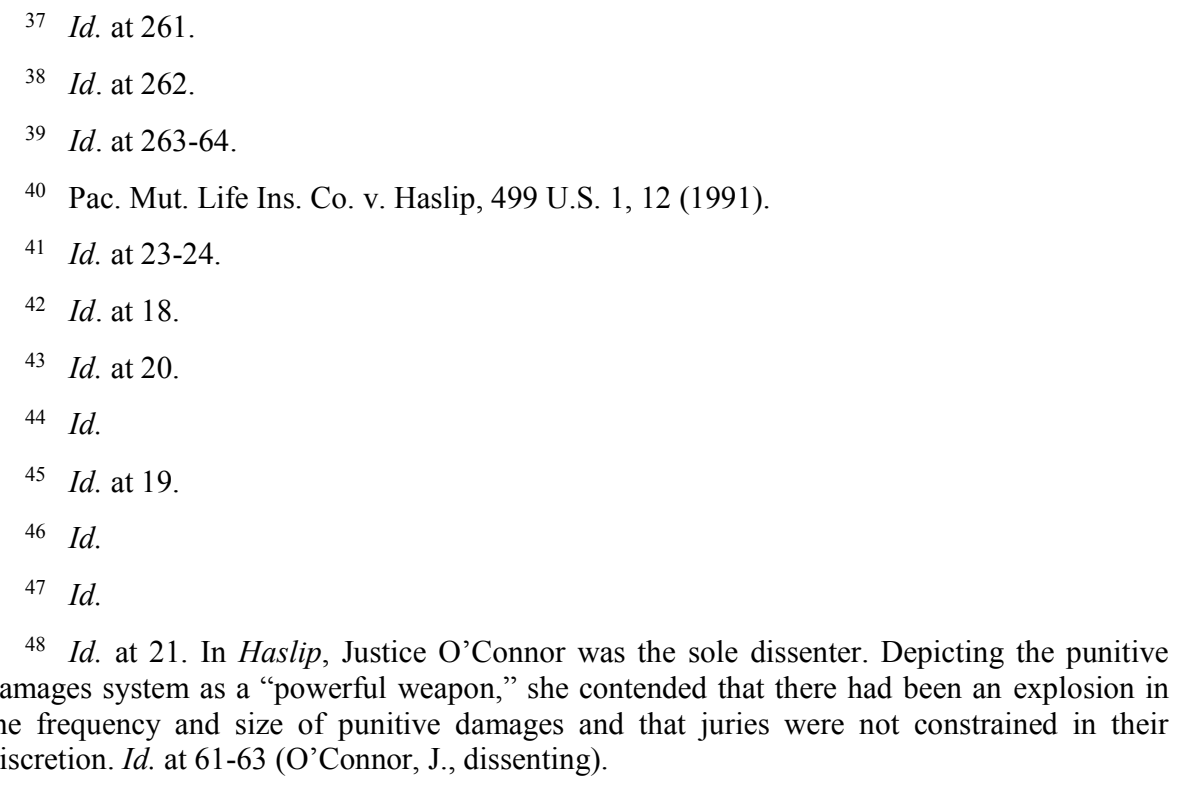


In 1993, the U.S. Supreme Court again upheld a punitive damages award in $T X O .^{49}$ In that case, the ratio of punitive damages to compensatory damages was remarkably 526 times larger than the compensatory damages awarded. ${ }^{50}$ The main issue the Court considered was whether the ratio violated the Due Process Clause. ${ }^{51}$ In support of its claim for punitive damages at trial, the plaintiff presented evidence that the defendant had "engaged in similar nefarious activities in its business dealings in other parts of the country." 52

Relying on Haslip, the Court declined to draw mathematical bright lines and went on to note that "it is appropriate to consider the magnitude of the potential harm that the defendant's conduct would have caused its intended victim . . . as well as the possible harm to other victims that might have resulted if similar future behavior were not deterred." ${ }^{3}$ Ultimately, the Court concluded that the punitive damage award was not excessive in light of due process because of the large amount of money at stake, the defendant's bad faith, a larger pattern of fraud and deceit, and the defendant's wealth. ${ }^{54}$ Thus, the Court's finding was that no due process violation occurred in $T X O^{55}$ or in Haslip. ${ }^{56}$

\section{B. BMW of North America v. Gore (1996) and its Aftermath: Punitive Damages} Awards Constitutionally Limited

The U.S. Supreme Court stated, for the first time, in its landmark decision of $B M W^{57}$, that excessive punitive awards could violate the Due Process Clause. ${ }^{58}$ In $B M W$, the defendant, a national dealership, failed to disclose that the brand new car it sold to the plaintiff had been repainted before delivery. ${ }^{59}$ At trial, the actual damages were only $\$ 4,000$, but the jury in Alabama awarded $\$ 4$ million in punitive damages (later reduced on appeal to $\$ 2$ million). ${ }^{60}$

The issue the Court considered in $B M W$ was whether the punitive damages award violated the Due Process Clause. ${ }^{61}$ Justice Stevens delivered the opinion for the Court and set forth a legal standard composed of three guideposts to test whether or not a punitive damage award is "grossly excessive" and too arbitrary to be

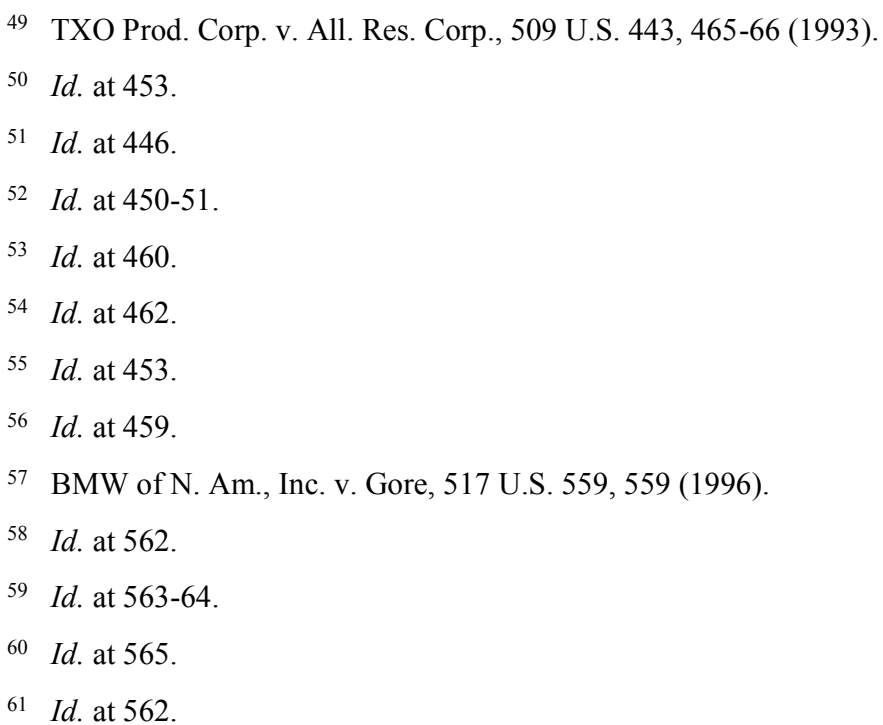


constitutional. ${ }^{62}$ The guideposts were based on the notion that the defendant should "receive . . f fair notice not only of the conduct that will subject him to punishment, but also of the severity of the penalty that a State may impose." 63 The first and "most important" guidepost is whether the damages are commensurate to the level of reprehensibility of the defendant's conduct. ${ }^{64}$ The second is whether a reasonable relationship exists between the amounts of compensatory and punitive damages. ${ }^{65}$ However, the Court refused to define what ratio constitutes "reasonable relationship." 66 The last guidepost is a comparison of the punitive damage award to the civil or criminal penalties imposed for equivalent conduct. ${ }^{67}$ The Court also held that punitive damages cannot punish a defendant for conduct committed in another state. ${ }^{68}$ Applying these three factors to the facts of the case, the Court concluded that the punitive damage award in this case was unconstitutionally excessive. ${ }^{69}$

In $B M W$, the votes were split. ${ }^{70}$ Justices Ginsburg and Rehnquist dissented on the grounds that states permitting punitive damages have an interest in punishment and deterrence and that the Court unwisely infringed on the realm of state law because the procedure fully satisfied due process. ${ }^{71}$ Justices Scalia and Thomas dissented on the substantive due process review and denounced the three guideposts as "a road to nowhere." 72

\section{State Farm (2003): Single Digit Rule}

In the next case, State Farm, the Court further strengthened the constraints on punitive damages. ${ }^{73}$ In a case for insurance bad faith arising out of the insurer's failure to settle a third-party liability claim, the jury awarded compensatory damages of $\$ 1$ million and punitive damages of $\$ 145$ million. ${ }^{74}$ Justice Kennedy, writing for the Court, slightly clarified the Court's second guidepost in $B M W$ and stated that "single-digit multipliers are more likely to comport with due process." 75 Based largely upon the fact that the ratio was 145 , the Court concluded that the punitive damages award in State Farm was constitutionally infirm. ${ }^{76}$

62 Id. at $574-75$.

63 Id. at 574 .

64 Id. at 575.

65 Id. at 580.

66 Id. at 582.

67 Id. at 583.

68 Id. at 572 .

69 Id. at 585-86.

70 Id. at 598 (Scalia, J., dissenting), 606 (Ginsburg, J., dissenting).

71 Id. at 607.

$72 I d$. at 605.

73 State Farm Mut. Auto Ins. Co. v. Campbell, 538 U.S. 408, 429 (2003).

74 Id. at 415.

75 Id. at 425.

76 Id. at 429 . 
The Court, however, acknowledged that a higher multiple may be constitutionally permissible depending upon the amount of compensatory damages. ${ }^{77}$ Specifically, the Court stated, "The precise award in any case, of course, must be based upon the facts and circumstances of the defendant's conduct and the harm to the plaintiff." 78

In State Farm, the Court also stated that punitive damages cannot punish a defendant for "dissimilar acts, independent from the acts upon which liability was premised." 79 It went on to hold that due process "does not permit courts, in the calculation of punitive damages, to adjudicate the merits of other parties' hypothetical claims against a defendant." 80 This principle turned out to be a foreshadowing of the main holding in Philip Morris, discussed below. ${ }^{81}$

\section{Philip Morris (2007): Procedural Due Process}

In 2007, three years after State Farm, the U.S. Supreme Court's decision in Philip Morris clarified the reprehensibility guidepost. ${ }^{82}$ This case involved an award of some $\$ 821,000$ in compensatory damages and $\$ 79.5$ million in punitive damages from litigation regarding the death of a heavy smoker in Oregon. ${ }^{83}$ The plaintiff alleged that the defendant cigarette manufacturer knowingly and falsely led him to believe that smoking was safe. ${ }^{84}$ The corporate defendant, Philip Morris, mainly argued that a portion of the $\$ 79.5$ million punitive damages award "represented punishment for its having harmed others." 85

The Court chose not to consider whether this award was grossly excessive. ${ }^{86}$ Instead, it focused on whether punitive damages can be based in part upon a jury's desire to punish the defendant for harming nonparty victims. ${ }^{87}$ The Court held that such awards cannot punish the defendant for causing harm to individuals who are not parties to the lawsuit and have their own tort claims against the defendant. ${ }^{88}$ Punishing the defendant for harm to nonparties violates the Due Process Clause for two reasons. First, such punishment deprives the defendant of an opportunity to defend itself against claims of injured nonparties. ${ }^{89}$ Second, punishment for harm to nonparties would "add a near standardless dimension to the punitive damages

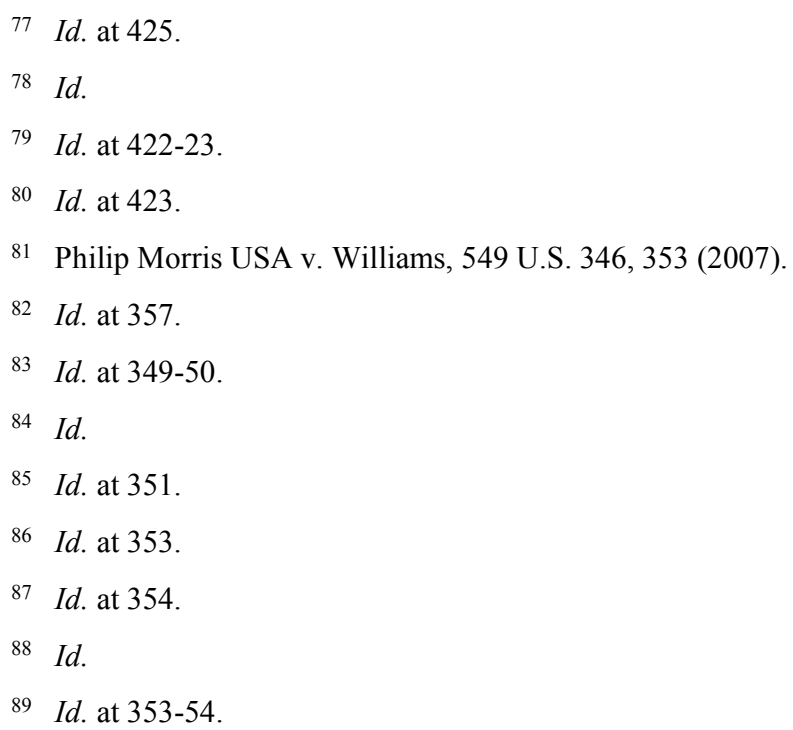


equation," ${ }^{90}$ if the calculation is based upon the amount of harmed nonparties, the extent of their injuries, and the circumstances of those injuries. ${ }^{91}$

Despite the above mentioned holding, the Court also noted that the jury may consider the defendant's conduct towards nonparties in determining reprehensibility, as "harm to others shows more reprehensible conduct." 92 In a nutshell, the main result of Philip Morris is that trial courts must provide "some form of protection" to ensure that the jury considers the evidence of harm to people other than the plaintiff when evaluating the reprehensibility of the defendant's conduct, but the jury should not consider this information when assessing the amount of punitive damages that might be awarded..$^{93}$

\section{E. Exxon (2008): One to One Ratio Rule}

In the Exxon decision, ${ }^{94}$ the U.S. Supreme Court finally settled the disputes over the unprecedented environmental disaster in 1989 involving the Exxon Valdez and at the same time addressed a challenge to the punitive damages award by establishing the "one to one ratio rule." 95 The corporate defendant, Exxon Shipping Co., was allegedly reckless in allowing a known alcoholic to captain a tanker carrying crude oil. The captain caused one of the greatest accidents ever, spilling eleven million gallons of crude oil into Prince William Sound. ${ }^{96}$ In the specific mandatory class action mainly brought by commercial fishermen for lost profits, the jury awarded $\$ 287$ million in compensatory damages and \$5 billion (later reduced to $\$ 2.5$ billion) in punitive damages against the defendant. ${ }^{97}$

Justice Souter, writing for the Court, began his discussion of the punitive damages award by holding that the case "goes to our understanding of the place of punishment in modern civil law and reasonable standards of process in administering punitive law." ${ }^{98}$ After reviewing the history of punitive damages, the Court declared, "The real problem, it seems, is the stark unpredictability of punitive awards." 99 It

$90 \quad$ Id. at 354.

$91 \quad I d$.

92 Id. at 355.

93 Id. at 357. In most cases, however, it is evidently hard for a jury to make this distinction. For example, Justice Stevens points out the problem with regard to the difference between reprehensibility and punishing for harm caused to nonparties: "When a jury increases a punitive damages award because injuries to third parties enhanced the reprehensibility of the defendant's conduct, the jury is by definition punishing the defendant . . . for third party harm." Id. at 360 (Stevens, J., dissenting).

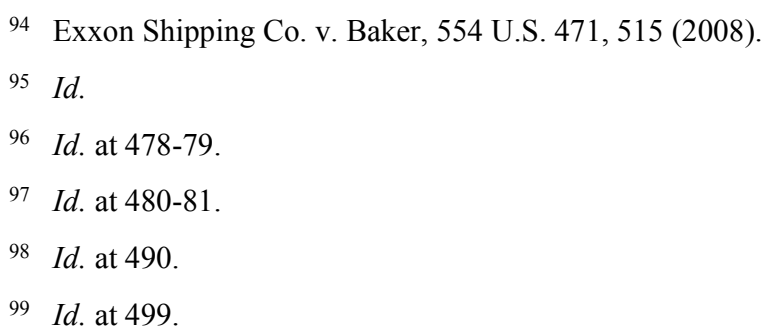


illustrated two cases with "strikingly similar facts," 100 where one jury awarded the plaintiff $\$ 4$ million in punitive damages and the other awarded the plaintiff none. ${ }^{101}$

The Court expressed skepticism that verbal formulations could work to promote "systematic consistency." 102 To better achieve predictability, it suggested that the fact finder "peg punitive to compensatory damages using a ratio or maximum multiple." 103 The amount of the multiplier should be based on the level of "blameworthiness within the punishable spectrum"104 and the amount of compensatory damages. ${ }^{105}$ If the amount is substantial, a lesser ratio is appropriate. If the amount is modest or the odds of detecting the harm are minimal, a higher ratio is appropriate. ${ }^{106}$ Heavily relying upon empirical scholarly studies, including Professor Eisenberg's thesis, ${ }^{107}$ the Court determined that a one-to-one ratio was appropriate in the Exxon case due to mere recklessness of the conduct and the substantial compensatory award. ${ }^{108}$

As Exxon was decided under the principles of maritime law, its scope seems to be limited. Furthermore, because it was a common law-based challenge, its expressed concern for predictability is not binding on the states, and Congress could potentially abrogate the holding with legislation. Some lower courts, however, have already begun to incorporate Exxon's concern for predictability within the constitutional analysis of punitive damages. ${ }^{109}$

\section{F. This Article's Contribution to an Understanding of Punitive Damages Awards}

While most of the prior empirical literature, which mainly deals with state trial court decisions, is helpful for understanding the realities of punitive damages at the state or trial level, the more illuminating questions involve the decisions of federal appellate courts. This article, specifically exploring the impact of the U.S. Supreme Court's decisions on federal circuit courts, provides a new perspective on how judges see the punitive damages regime within the U.S. Supreme Court's framework. This is because circuit court judges are more likely than trial judges to hew to the Supreme Court's holdings.

This study also empirically clarifies the differences in impact of the U.S. Supreme Court's decisions on lower courts. Conventional or traditional legal studies tend to look into the texts of the Court's decisions and the backgrounds of those cases. Our data, on the other hand, attempts to explore whether or not the U.S.

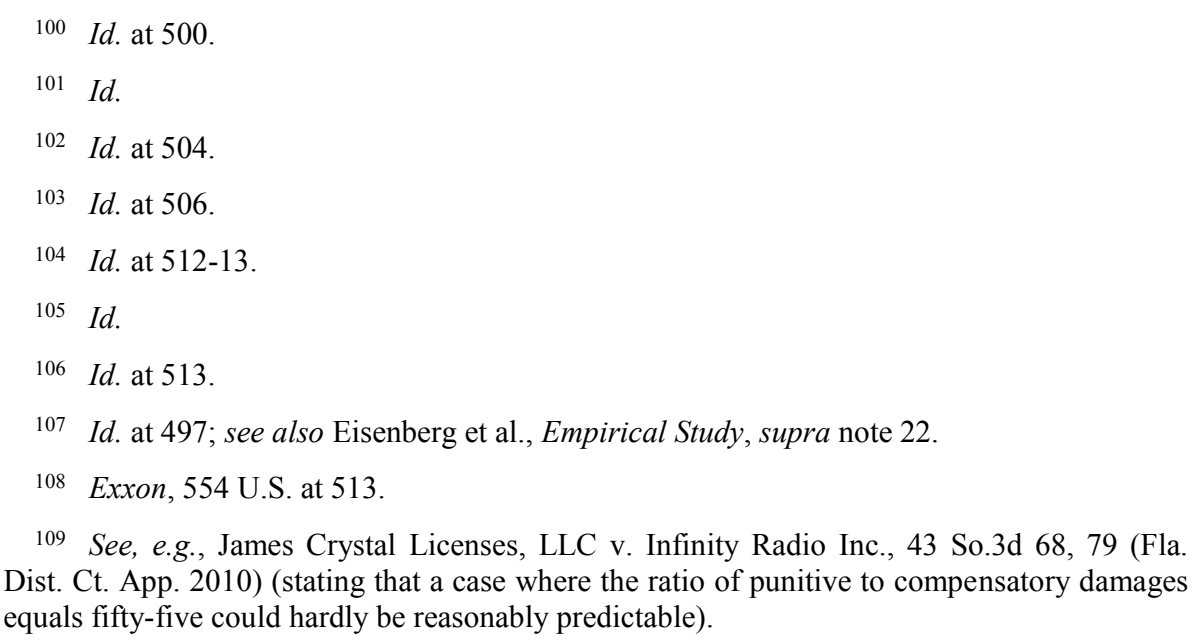


Supreme Court doctrine functions as a proxy for shifts in appellate court behavior, as demonstrated by empirical evidence. Hence, our findings may provide a more multidimensional perspective on the Court's holdings.

\section{DATA AND MAIN RESULTS}

\section{A. The Data Used in This Study}

The data for this study, covering the last eight years (from November 1, 2004, to October 31, 2012), comes from the Lexis-Nexis Academic database. After a cursory reading of 1,115 federal circuit court cases, gathered by the key words "punitive damages" as legal terms, $318(28.5 \%)$ of those cases were ones in which punitive damage awards had been granted (most of which were by federal district courts). ${ }^{110}$ The remaining 797 (71.5\%) cases were ones in which the plaintiffs did not prevail, were awarded compensatory damages only, or ones which have little relevance to this study, despite judicial reference to punitive damages in written decisions. ${ }^{111}$

\section{B. The Punitive to Compensatory Damages Ratio}

Table 1 shows the median and mean of punitive and compensatory awards granted in cases with punitive damages awards, as well as the punitive to compensatory damages ratio. Because there are fifteen cases where the adjudicators (jury or judge) awarded $\$ 0$ in compensatory damages, the number of the ratio is 303 .

The difference between mean and median is glaring and striking, especially with regard to punitive damages awarded. The amount of the mean punitive damages is $\$ 493,195,929,{ }^{112}$ while the amount of median is $\$ 500,000,{ }^{113}$ which seems mediocre. The same holds true for the punitive to compensatory damages ratio. The reason why the mean punitive damages award or ratio is extremely high is simple: several outliers, such as the $\$ 5$ billion punitive award in In re Exxon Valdez, ${ }^{114}$ tend to inflate the mean. When focusing solely on the mean award amount, it might safely be said that punitive damages are unpredictable and continue to "run wild," as a number of tort reformers assert.

However, what is important when gauging punitive awards is not mean, but rather median, because the latter outweighs the former in that it could exclude the impact of outliers.

Now, let us examine the median punitive to compensatory damages ratio. Although the median 2.11 seems relatively higher than $0.62^{115}$ or $0.67^{116}$ in the prior literatures, it is not considerably high, given that all the cases in this study are from

110 Hironari Momioka, Data Set Composed of 318 Cases to Assess Punitive Damages (on file with the author) [hereinafter Momioka, Data Set].

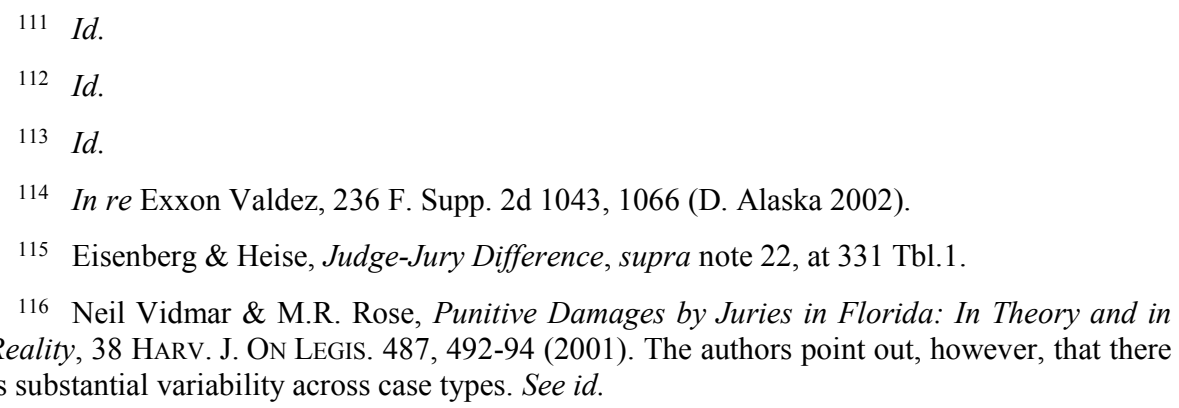


federal circuit courts. At that level of court, it is understandable that in almost all the cases the punitive damages amounts awarded were fairly large for the defendants. In that respect, we can say that the median ratio calculated in our study does not contradict, but instead supports, precedent studies.

Table 1: Median and Mean Punitive and Compensatory Awards, 2004-2012

\begin{tabular}{|c|c|c|c|}
\hline & Median & Mean & N \\
\hline Punitive Award & 500,00 & $493,195,929$ & 318 \\
\hline $\begin{array}{c}\text { Compensatory } \\
\text { Award }\end{array}$ & 250,163 & $17,117,135$ & 318 \\
\hline $\begin{array}{c}\text { Punitive to } \\
\text { Compensatory } \\
\text { Ratio }\end{array}$ & 2.11 & 8775.16 & 303 \\
\hline
\end{tabular}

Note: The data covers the time from November 1, 2004 to October 31, 2012. When calculating the ratio, 15 cases have been excluded where the plaintiff won a zero compensatory award (ratio incalculable)

Data Source: Lexis-Nexis Database

\section{Judge-Jury Differences}

We next compare jury awards with awards ordered by judges sitting alone, focusing on the ratio of punitive to compensatory awards. A ratio is, as discussed in Section II, described by quite a few scholars and in the Supreme Court decisions as an important "barometer of whether a punitive damages award is out of line." 117 Table 2 reports by adjudicator, the medians, the means, their significances of difference, and the numbers of observations.

The Table's last column shows the observations. Litigants chose jury trials at an overwhelmingly higher rate than trial by judge alone. The rate at which litigants (a plaintiff, a defendant, or both) chose jury trials was $83.82 \%$, though fifteen cases in which the compensatory awards were zero have been excluded for ease of calculation. ${ }^{118}$ The result demonstrates that litigants' preference for jury trials in federal courts is almost the same as in the state courts. At the state court level, the rate at which litigants chose jury trials was $81.26 \%$, in cases where both punitive and compensatory damages were awarded. ${ }^{119}$

The third column indicates medians. The judge-jury difference between 1.37 and 2.43 seems outstanding but is not statistically significant (a significant level is 5\%), as shown in the fourth column. ${ }^{120}$ It is only in punitive damages awards that adjudicator difference shows a high statistical significance. According to the fifth and sixth columns, all means, including punitive to compensatory ratio, indicate no statistical difference. Thus, one could conclude that there seems to be no difference in assessing damages, as between jury and judge, as far as the cases before the

117 Hersch \& Viscusi, Perform, supra note 24, at 8-9.

118 Momioka, Data Set, supra note 110, at Tbl.2.

119438 jury trials and 101 bench trials, according to the data from Civil Justice Survey of State Courts 1992-2001. See Theordore Eisenberg et al., Judges, Juries, and Punitive Damages: Empirical Analyses Using the Civil Justice Survey of State Courts 1992, 1996, and 2001 Data, 2 J. EMPIRICAL LeGAL StUD. 263, 269 Tbl.1 (2006).

120 Momioka, Data Set, supra note 110, at Tbl.2. 
federal appellate courts are concerned. It is also noteworthy that both the median ratios are far below the standard held in State Farm ("single digit"- that is, less than 10 times). ${ }^{121}$

Table 2: Median and Mean Punitive and Compensatory Awards, by Adjudicator

\begin{tabular}{|c|c|c|c|c|c|c|}
\hline & Adjudicator & Median & $\begin{array}{c}\text { Significance } \\
\text { of } \\
\text { Adjudicator } \\
\text { Difference }\end{array}$ & Mean & $\begin{array}{c}\text { Significance } \\
\text { of } \\
\text { Adjudicator } \\
\text { Difference }\end{array}$ & N \\
\hline Punitive Award & Jury & 503,424 & & $\begin{array}{c}493,19 \\
5,929\end{array}$ & 254 \\
\hline & Judge & 200,000 & $0.0034 * *$ & 600,21 & 0.3756 & 49 \\
\hline $\begin{array}{c}\text { Compensatory } \\
\text { Award }\end{array}$ & Jury & 3000,00 & & $\begin{array}{c}17,117 \\
135\end{array}$ & \\
\hline $\begin{array}{c}\text { Punitive to } \\
\text { Compensatory }\end{array}$ & Judge & 214,000 & 0.4691 & $4,959,1$ & 0.1795 & 254 \\
\hline Ratio & Jury & 2.43 & 0.0581 & 15 & & 49 \\
\hline
\end{tabular}

Note: $* * p<0.01$. The significance mean difference is based upon a MannWhitney test; the significance mean difference is based upon a t-test.

Data Source: Lexis-Nexis Database

Figure 1 is a scatter-plot of logged punitive and compensatory damages with jury and judge trials from our data. ${ }^{122}$ In this figure, logarithmic scales are employed, since linear scales and untransformed data often fail to clarify the relations between the variables. Using logged data is a proper and valid method ${ }^{123}$ when dealing with damages, inter alia, punitive awards, because they are quite rarely normally distributed and could hardly assume standard regression. The best fitting regression lines for jury and judge trials also appear there. Intuitively, we can find that these two lines are similar in light of gradient and intercept.

121 Id.; State Farm Mut. Auto Ins. Co. v. Campbell, 538 U.S. 408, 425 (2003).

122 Momioka, Data Set, supra note 110, at Fig.1.

123 For validity of using logarithmic scales, see generally ANDREW GELMAN \& JENNIFER Hill, Data Analysis Using Regression and Multilevel/Hierarchical Models 59-65 (2007). 
Figure 1: Punitive to compensatory Awards (logs) by Adjudicator

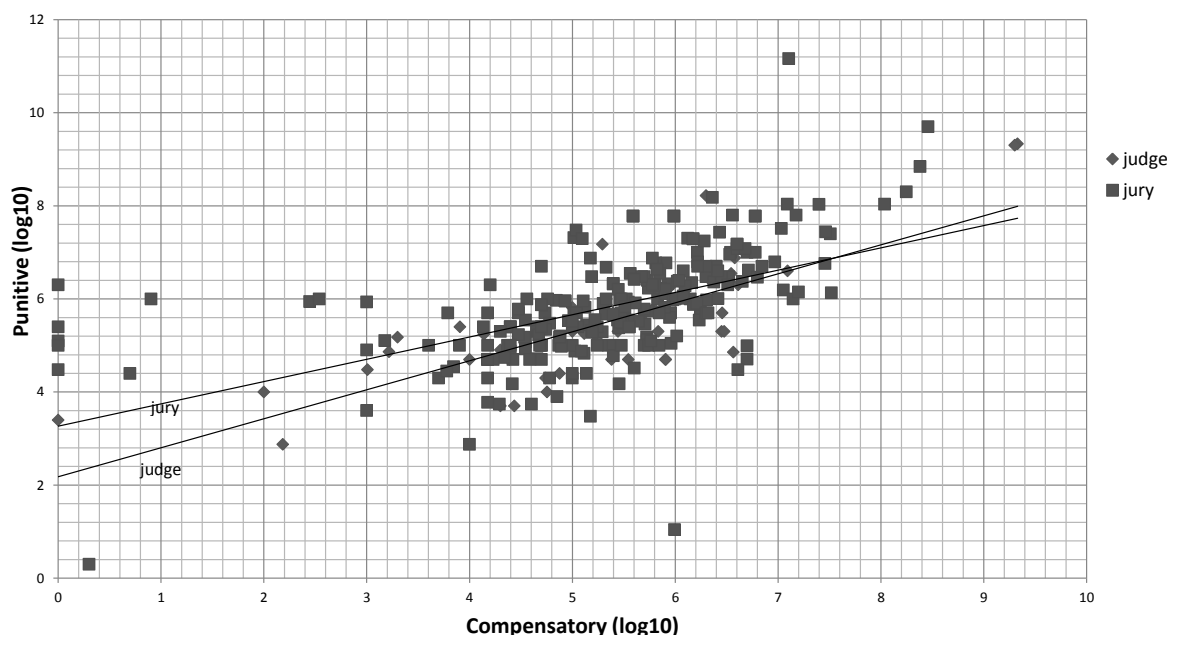

Note: Lines are the best-fitting linear regression lines for jury and judge trials. Data Source: Lexis-Nexis Database.

Table 3 shows the ratios of logged transformed punitive to compensatory damages awards. As the third and fifth columns indicate, there is no significant difference between a jury or judge as adjudicators in both median and mean. ${ }^{124}$ To put it another way, juries and judges perform almost the same when assessing damages. Furthermore, these findings are generally in harmony with prior studies. ${ }^{125}$

Table 3: Ratio of Logged Punitive to Compensatory Awards, by Adjudicator

\begin{tabular}{|c|c|c|c|c|c|}
\hline Adjudicator & Median & $\begin{array}{c}\text { Significance } \\
\text { of } \\
\text { Adjudicator } \\
\text { Difference }\end{array}$ & Mean & $\begin{array}{c}\text { Significance } \\
\text { of } \\
\text { Adjudicator } \\
\text { Difference }\end{array}$ & N \\
\hline Jury & 1.0061 & 0.1059 & 1.2079 & 0.2162 & 254 \\
\hline Judge & 1.0268 & 1.1133 & 49 \\
\hline
\end{tabular}

Note: The significance median difference is based upon a Mann-Whitney test; the significance mean difference is based upon a t-test.

Data Source: Lexis Nexis

\section{Case Category, Case Types, Party Status, and Locale}

This Section mainly explores the ratios of logged punitive to compensatory damages by case category, party status, and locale. Table 4 summarizes the number and percentage of jury and judge trial characteristics, and the second and third columns show the number of jury and judge-only trials, respectively.

124 Momioka, Data Set, supra note 110, at Tbl.3.

125 See, e.g., Eisenberg et al., Empirical Study, supra note 22; Eisenberg, Variability in Punitive Damages, supra note 22, at 13; see also Hersch \& Viscusi, Perform, supra note 24, at 36 (highlighting the judge-jury difference in assessing the punitive awards). 
As the rows of "Case Category" and "Case Types" in Table 4 illustrate, nearly one-half (49.1\%) of the punitive damages cases involve civil rights, such as 42 U.S. $\S 1983$ (torts by federal or state government officials), ${ }^{126} 42$ U.S. $\S 1981$ (employment discrimination or dispute), ${ }^{127}$ and Americans Disabilities Act (ADA). ${ }^{128}$ This trend is strikingly different from state courts. ${ }^{129}$ Juries see a disproportionate number of civil rights cases; of the 156 civil rights cases, 146 (93.6\%) were jury trials. ${ }^{130}$

As for the row of "Case Types," we categorize each case to only one type though disputes could involve more than one claim, and there could be an overlap across the claim types. Notably, the combined number of $\S 1981$ and $\S 1983$ litigations alone account for as much as $39.4 \%{ }^{131}$ Also notable is that jury trials dominate those punitive damages cases $(92.0 \%) .{ }^{132}$ The second largest portion belongs to business torts cases, which include insurance, malpractice, copyright infringement, product liability, and so forth. ${ }^{133}$

As the "Party Status" column indicates, we categorize all of the punitive damages cases into four groups. For those cases that involve multiple plaintiff or defendant types, cases are categorized based on the importance of each litigant. In more than one-half of the cases (64.2\%), the plaintiff was an individual, and the defendant was a non-individual, such as a corporation, hospital, or government. ${ }^{134}$ Furthermore, most of the cases were decided by a jury. The results illustrate the popular and typical lore that individual victims can bring lawsuits against big companies with deep pockets and be awarded huge punitive damages through jury verdicts.

The distribution of jury-judge punitive damages awards cases, by locale, varies considerably. Almost all punitive damages cases were tried by juries in one region (Fourth Circuit), ${ }^{135}$ while judge-only trials accounted for $25.6 \%$ in another region (Ninth Circuit). ${ }^{136}$

\footnotetext{
126 Momioka, Data Set, supra note 110, at Tbl.4.

127 Id.

$128 I d$.

129 See, e.g., Eisenberg \& Heise, Judge-Jury Difference, supra note 22, at 333 Tbl.2.

130 Momioka, Data Set, supra note 110, at Tbl.4.

131 Id.

132 Id.

133 Id.

134 Id.

135 Id.

136 Id.
} 
Table 4: Summary of Jury and Judge Trial Characteristics in Punitive Damages Cases

\begin{tabular}{|c|c|c|c|}
\hline & Jury & Judge & $\begin{array}{c}\text { Percent of Total } \\
\text { Cases }\end{array}$ \\
\hline \multicolumn{4}{|c|}{ Case Category } \\
\hline Civil Rights & 146 & 10 & 49.1 \\
\hline Business Torts & 90 & 22 & 35.2 \\
\hline Others & 28 & 22 & 15.7 \\
\hline \multicolumn{4}{|c|}{ Case Types } \\
\hline$\S 1983$ & 60 & 6 & 20.8 \\
\hline $\begin{array}{c}\text { Employment } \\
\text { Discrimination or } \\
\text { Dispute }\end{array}$ & 55 & 4 & 18.6 \\
\hline Insurance & 20 & 2 & 6.9 \\
\hline Financial Dispute & 12 & 5 & 5.3 \\
\hline Copyrights & 3 & 1 & 1.3 \\
\hline Product Liability & 6 & 1 & 2.2 \\
\hline $\begin{array}{c}\text { Defamation and } \\
\text { Privacy }\end{array}$ & 6 & 3 & 2.8 \\
\hline Other Torts & 72 & 12 & 26.4 \\
\hline Contract & 20 & 8 & 8.8 \\
\hline Bankruptcy & 0 & 8 & 2.5 \\
\hline Others & 10 & 4 & 4.4 \\
\hline \multicolumn{4}{|c|}{ Party Status } \\
\hline $\begin{array}{l}\text { Individual Plaintiff } \\
\text { v. Individual } \\
\text { Defendant }\end{array}$ & 32 & 12 & 13.8 \\
\hline $\begin{array}{l}\text { Individual Plaintiff } \\
\text { v. Non-Individual } \\
\text { Defendant }\end{array}$ & 180 & 24 & 64.2 \\
\hline $\begin{array}{l}\text { Non-Individual } \\
\text { Plaintiff v. } \\
\text { Individual } \\
\text { Defendant }\end{array}$ & 4 & 5 & 2.8 \\
\hline $\begin{array}{l}\text { Non-Individual } \\
\text { Plaintiff v. Non- } \\
\text { Individual } \\
\text { Defendant }\end{array}$ & 48 & 13 & 19.2 \\
\hline \multicolumn{4}{|c|}{ Locale } \\
\hline $\begin{array}{c}\text { Circuit of District of } \\
\text { Columbia }\end{array}$ & 2 & 1 & 0.9 \\
\hline 1st Circuit & 20 & 2 & 6.9 \\
\hline 2nd Circuit & 15 & 4 & 6.0 \\
\hline 3rd Circuit & 26 & 2 & 8.8 \\
\hline 4th Circuit & 18 & 1 & 6.0 \\
\hline 5th Circuit & 21 & 7 & 8.8 \\
\hline 6th Circuit & 31 & 8 & 12.3 \\
\hline
\end{tabular}




\begin{tabular}{|c|c|c|c|}
\hline 7th Circuit & 21 & 5 & 8.2 \\
\hline 8th Circuit & 29 & 7 & 11.3 \\
\hline 9th Circuit & 32 & 11 & 13.5 \\
\hline 10th Circuit & 29 & 3 & 10.1 \\
\hline $11^{\text {th }}$ Circuit & 20 & 3 & 7.2 \\
\hline $\mathbf{N}$ & 264 & 54 & \\
\hline
\end{tabular}

Note: Total Cases, $\mathrm{N}=318$.

Data Source: Lexis-Nexis Database.

\section{Case Category}

Figure 2 explores the relationship between compensatory and punitive awards by case category. It illustrates a general pattern of awarding punitive damages: the business torts regression line is steeper than the civil rights line, indicating that juries or judges tend to award greater punitive damages in business disputes than in civil rights cases.

Figure 2: Punitive to Compensatory Awards (logs) by Case Category

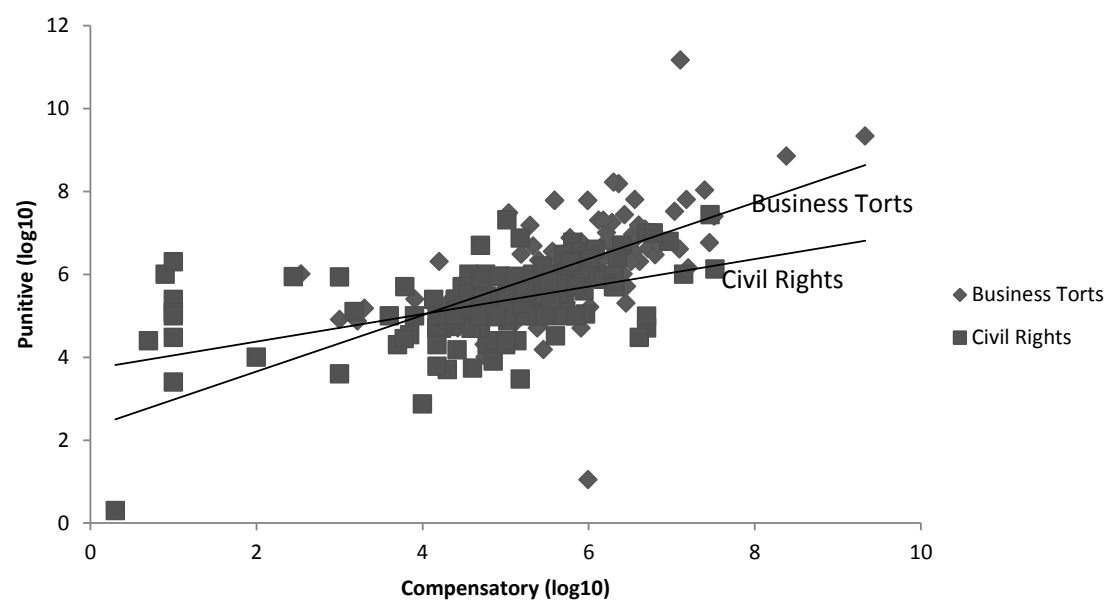

\section{Litigant Type}

Although party status was categorized into four groups in Table 4, we focus solely on cases involving two types of defendants (individual and non-individual) here to facilitate comparisons. The exploration will also provide us with insight into the relationship between the defendant's wealth and the amount of punitive damages awarded.

As displayed in Table 5, almost all differences between individual and nonindividual defendants are not statistically significant. There is, however, one exception (median of punitive award), suggesting that non-individual defendants such as wealthy companies have to pay large amounts of punitive damages. It is also noteworthy that the average of compensatory awards for individual parties is larger than that for non-individual parties, and the average of punitive damages awards for 
individuals is smaller than that for non-individuals, though the difference is not significant in either case.

Table 5: Median and Mean Punitive and Compensatory Awards, by Status of Defendant

\begin{tabular}{|c|c|c|c|c|c|c|}
\hline & $\begin{array}{c}\text { Status of } \\
\text { Defendant }\end{array}$ & Median & $\begin{array}{c}\text { Significance } \\
\text { of Status } \\
\text { Difference }\end{array}$ & Mean & $\begin{array}{c}\text { Significance } \\
\text { of Status } \\
\text { Difference }\end{array}$ & $\mathbf{N}$ \\
\hline \multirow{2}{*}{$\begin{array}{l}\text { Punitive } \\
\text { Award }\end{array}$} & Individual & 250,000 & \multirow{2}{*}{$0.0249 * * *$} & $44,423,572$ & \multirow{2}{*}{0.3260} & 53 \\
\hline & $\begin{array}{c}\text { Non- } \\
\text { Individual }\end{array}$ & 500,000 & & $610,812,855$ & & 265 \\
\hline \multirow{2}{*}{$\begin{array}{c}\text { Compensatory } \\
\text { Award }\end{array}$} & Individual & 213,000 & \multirow{2}{*}{0.2235} & $40,267,362$ & \multirow{2}{*}{0.5059} & 53 \\
\hline & $\begin{array}{c}\text { Non- } \\
\text { Individual }\end{array}$ & 300,00 & & $13,397,682$ & & 265 \\
\hline \multirow{2}{*}{$\begin{array}{c}\text { Punitive to } \\
\text { Compensatory } \\
\text { Ratio }\end{array}$} & Individual & 2.05 & \multirow[b]{2}{*}{0.8499} & $2,557.15$ & \multirow[b]{2}{*}{0.367} & 53 \\
\hline & $\begin{array}{c}\text { Non- } \\
\text { Individual }\end{array}$ & 2.13 & & $10,033.57$ & & 265 \\
\hline
\end{tabular}

Note: $* * * p<0.005$. The significance median difference is based upon a Mann-

Whitney test; the significnce mean difference is based upon a t-test.

Data Source: Lexis-Nexis Database

\section{E. The Supreme Court Decisions and Circuit Court Judges}

A concern in using data spanning eight years is whether the circuit court judges have hewed to or stayed current with the U.S. Supreme Court decisions, such as Philip Morris or Exxon, when it comes to dealing with the punitive awards cases before them. It seems self-evident that lower courts follow what the U.S. Supreme Court holds because case law, based upon the doctrine of stare decisis, rather than statutory law, dominates or rules in the Anglo-American legal system. ${ }^{137}$

However, according to the results of this study, it is not the case that stare decisis dominates where the punitive damages regime is concerned. This Section attempts to show that the impact of U.S. Supreme Court decisions on federal circuit courts is mixed at best.

\section{Punitive Damages over Time: Ratio by Year}

Table 6 represents the result of medians of punitive to compensatory ratios and punitive and compensatory awards by year. As a whole, the ratio seems stable. Taking a close look at the changes of ratios by year, however, it is true that the ratio dropped in 2009, 2010, and 2011, shortly after Exxon. ${ }^{138}$ What is beyond comprehension is that, as illuminated in Figure 3, there was a sudden increase in the ratio in 2012. ${ }^{139}$ It is also not clear why the median ratio in 2008 is as high as 3.33, which exceeds all the other years. ${ }^{140}$ All trends considered, the ups and downs seem

\footnotetext{
137 Id. at Tbl.5.

138 Id. at Tbl.6.

139 Id. at Fig.3.

140 Id. at Tbl.7.
} 
inexplicable and unrelated to the U.S. Supreme Court decisions, as the reasoning in Philip Morris and Exxon cannot explain the ratio trend completely. In other words, if the U.S. Supreme Court's intention to curb the level of damages awarded had functioned, the ratio should have decreased.

Despite the foregoing, we cannot totally exclude the possibility that the two decisions might have restrained punitive damages awards. An analysis of the ratio change alone does not provide insight into the impact of U.S. Supreme Court decisions on the federal circuit court punitive damages regime.

Table 6: Punitive to Compensatory Ratio By Year

\begin{tabular}{|c|c|c|c|c|c|c|c|c|c|}
\hline Year & $\mathbf{2 0 0 4}$ & $\mathbf{2 0 0 5}$ & $\mathbf{2 0 0 6}$ & $\mathbf{2 0 0 7}$ & $\mathbf{2 0 0 8}$ & $\mathbf{2 0 0 9}$ & $\mathbf{2 0 1 0}$ & $\mathbf{2 0 1 1}$ & $\mathbf{2 0 1 2}$ \\
\hline $\begin{array}{c}\text { Median } \\
\text { Punitive to } \\
\text { Compensatory }\end{array}$ & 2.81 & 2.15 & 1.76 & 2.43 & 3.33 & 2.00 & 1.67 & 1.91 & 3.17 \\
\hline $\begin{array}{c}\text { Ratio } \\
\text { Median } \\
\text { Punitive } \\
\text { Awards }\end{array}$ & 331,250 & 500,00 & 200,000 & 930,000 & 472,300 & 550,00 & 503,424 & 750,000 & 350,000 \\
\hline $\begin{array}{c}\text { Median } \\
\text { Compensatory } \\
\text { Awards }\end{array}$ & 75,00 & 2877,736 & 255,000 & 291,000 & 106,000 & 304,000 & 282,853 & 486,932 & 350,000 \\
\hline $\begin{array}{c}\text { Number of } \\
\text { Cases }\end{array}$ & 7 & 52 & 43 & 47 & 41 & 40 & 34 & 25 & 29 \\
\hline
\end{tabular}

Note: Year of 2004 ranges from November 1 to December 13, Year of 2012 ranges from Janurary 1 to October 31, and the rest range from Janurary 1 to December 31

Data Source: Lexis-Nexis Database

Figure 3:Median Punitive to Compensatory Ratio

Figure 3: Median Punitive to Compensatory Ratio

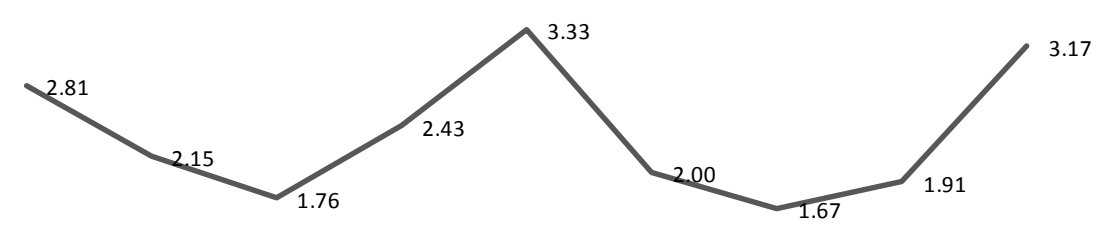

$\begin{array}{lllllllll}2004 & 2005 & 2006 & 2007 & 2008 & 2009 & 2010 & 2011 & 2012\end{array}$

2. Punitive Damages over Time: Ratio by Period

In that regard, we undertake two kinds of data analysis, dividing the eight-year period into two parts: pre/post Philip Morris and pre/post Exxon. 
Table 7 shows the data of the impact of Philip Morris on federal circuit courts. The untransformed median has slightly risen (from 2.00 to 2.32), ${ }^{141}$ which seems to be contrary to the U.S. Supreme Court's intention. Statistically speaking, its attempt to restrict the ratio may not have been fully accomplished. Yet, as the third column indicates, the change of median is insignificant. The slight rises of logged median and mean are also insignificant.

Table7: Ratio of Punitive to Compensatory Awards, pre/post Phillip Morris (2007)

\begin{tabular}{|c|c|c|c|c|c|c|c|c|}
\hline Period & $\begin{array}{l}\text { Untransformed } \\
\text { Median }\end{array}$ & $\begin{array}{c}\text { Significance } \\
\text { of pre/post } \\
\text { Phillip } \\
\text { Morris } \\
\text { Difference }\end{array}$ & $\mathbf{N}$ & $\begin{array}{l}\text { Logged } \\
\text { Median }\end{array}$ & $\begin{array}{c}\text { Significance } \\
\text { of pre/post } \\
\text { Phillip } \\
\text { Morris } \\
\text { Difference }\end{array}$ & $\begin{array}{l}\text { Logged } \\
\text { Mean }\end{array}$ & $\begin{array}{c}\text { Significance } \\
\text { of pre/post } \\
\text { Phillip } \\
\text { Morris } \\
\text { Difference }\end{array}$ & $\mathbf{N}$ \\
\hline $\begin{array}{c}\text { Pre- } \\
\text { Phillip } \\
\text { Morris }\end{array}$ & 2.00 & \multirow{2}{*}{0.3533} & 107 & 1.0576 & 0.4462 & 1.0957 & \multirow{2}{*}{0.5150} & 105 \\
\hline $\begin{array}{l}\text { Post- } \\
\text { Phillip } \\
\text { Morris }\end{array}$ & 2.32 & & 196 & 1.0639 & 1.1284 & 1.1284 & & 192 \\
\hline
\end{tabular}

Note: The data covers the time period from November 1, 2004 to October 31, 2012. "Logged" stands for log (10). When calculating logged median and mean, six cases have been excluded, where logged compensatory damages are zero (ratio incalculable.) The significance median difference is based upon a MannWhitney test; the significance mean difference is based upon a t-test.

Data Source: Lexis-Nexis Database

Likewise, Table 8 shows the influence of Exxon on lower courts. As opposed to Philip Morris, the median (untransformed) dropped from 2.30 to 2.00 after Exxon, ${ }^{142}$ which seems to indicate a change for the better as the U.S. Supreme Court has hoped for years. The slight decline, however, is not statistically significant. Although the logged means do marginally differ, logged medians do not show a significant difference $(\mathrm{p}=0.5150<0.10) .{ }^{143}$

To put it briefly, what Tables 7 and 8 suggest is quite simple and obvious: neither Philip Morris nor Exxon changed the attitudes of lower federal circuit courts toward the ratio of punitive to compensatory damages. These results are precisely the opposite of what was predicted.

\footnotetext{
141 Id. at Tbl.8.

142 Id. at Tbl.8. n.1.

143 Id.
} 
Table 8: Ratio of Punitive to Compensatory Awards, pre/post Exxon (2008)

\begin{tabular}{|c|c|c|c|c|c|c|c|c|}
\hline Period & $\begin{array}{c}\text { Untransformed } \\
\text { Median }\end{array}$ & $\begin{array}{c}\text { Significance } \\
\text { of pre/post } \\
\text { Exxon } \\
\text { Difference }\end{array}$ & $\mathbf{N}$ & $\begin{array}{c}\text { Logged } \\
\text { Median }\end{array}$ & $\begin{array}{c}\text { Significance } \\
\text { of pre/post } \\
\text { Exxon } \\
\text { Difference }\end{array}$ & $\begin{array}{c}\text { Logged } \\
\text { Mean }\end{array}$ & $\begin{array}{c}\text { Significance } \\
\text { of pre/post } \\
\text { Difference }\end{array}$ & N \\
\hline $\begin{array}{c}\text { Pre- } \\
\text { Exxon }\end{array}$ & 2.30 & 0.6181 & 163 & 1.0662 & & 1.1628 & 161 \\
\hline $\begin{array}{c}\text { Post- } \\
\text { Exxon }\end{array}$ & 2.00 & 140 & 1.0525 & & & & & \\
\hline
\end{tabular}

Note: The data covers the time period November 1, 2004 to October 31, 2012.

"Logged" stands for log (10.) When calculating logged median and mean, six cases have been excluded, where logged compensatory damages are zero (ratio incalculable.) The significance median difference is based upon a Mann-Whitney test; the significance mean difference is based upon a t-test. $* * * *$ Difference pre/post Exxon is significant at $\mathrm{p}<0.10$.

Data Source: Lexis-Nexis Database.

\section{Reduced Damages (Remittitur)}

Trial judges are entitled to reduce the amount of damages, including punitive damages, within their discretion if they believe that granted awards are improper. This power is called "remittitur." 144 When a defendant agrees to a proposed amount, a judge can enter the judgment. In practice, district judges frequently use this procedure when awarding punitive damages. ${ }^{145}$ This Section explores the impact of the Exxon decision on damage reductions. Here, we will examine whether judges have demonstrated a tendency to reduce the amount of awards more after Exxon, as opposed to before the decision.

Out of 318 cases, we found sixty-seven cases in which punitive damages awards were reduced. ${ }^{146}$ In most cases, trial judges reduced punitive damages awards granted by juries (remittitur) in prior proceedings. However, there were also two cases in which punitive damages awards resulting from judge-only trials were reduced. The fact that only $21.07 \%(67 / 318)$ of the cases resulted in an award

144 See generally Linda L. Schlueter, Punitive Damages 443-51 (6th ed. 2010). On the contrary, trial judges are also entitled to raise the damages if they believe an amount of damages is too small. This procedure is called additur. See David Baldus et al., Improving Judicial Oversight of Jury Damages Assessments: A Proposal for the Comparative Additur/Remittitur Review of Awards for Nonpecuniary Harms and Punitive Damages, 80 IowA L. REV. 1109, 1119 (1995). None of the trials in this study involve additur.

145 As one court correctly stated, "Remittitur plays an important role in judicial economy by encouraging an end to litigation rather than a new trial." Wightman v. Consol. Rail Corp., 715 N.E.2d 546, 556 (Ohio 1999).

146 Momioka, Data Set, supra note 110. 
reduction might suggest that trial or circuit court judges tend to show deference to the conclusions of fact finders like juries and trial court judges.

Table 9 indicates the result of punitive award reductions. In this section, the increasing rate stands for the rate of the latter to the former value minus one. For example, if the amount of the pre-Exxon punitive award was 500,000, and the postExxon award 120,000, the increasing rate equals 1-120,000/500,000-namely, $76.00 \%$ (decreasing rate: $76 \%$ ). ${ }^{147}$

With regard to medians and means of the decreasing rate, the period after the Exxon decision shows a drop (17.34\% and $14.84 \%$, respectively). Each indicator strikingly demonstrates a statistically significant difference. The result evidently suggests that after the Exxon decision, lower court judges tend to limit punitive damages awards much more than before the case was decided. Although it is not apparent that Exxon is the only dominant reason for the decrease in the level of punitive awards, it is true that both the median and mean indicate a drop after 2008.

The drop in numbers after 2008 also suggests a difference in terms of the decision's influence on juries and judges. It is quite natural and understandable that trial and circuit court judges, as experienced repeat-players, are more or less aware of U.S. Supreme Court decisions and have an intrinsic incentive to adhere to legal doctrines; on the other hand, less experienced lay juries, as one-time players, do not have to be well-informed of jurisprudence. The result of this study comports with the Eisenberg's finding that "in general, court decisions-including many (but not all) Supreme Court decisions - tend to be absorbed and propagated by judges more directly than by lay jurors." 148

Table 9: Increasing Rate of Punitive Awards, pre/post Exxon (2008), Cases with Reduction

\begin{tabular}{|c|c|c|c|c|c|}
\hline Period & $\begin{array}{c}\text { Median } \\
(\%)\end{array}$ & $\begin{array}{c}\text { Significance } \\
\text { of pre/post } \\
\text { Exxon } \\
\text { Difference }\end{array}$ & $\begin{array}{c}\text { Mean } \\
\mathbf{( \% )}\end{array}$ & $\begin{array}{c}\text { Significance } \\
\text { of pre/post } \\
\text { Exxon } \\
\text { Difference }\end{array}$ & N \\
\hline $\begin{array}{c}\text { Pre- } \\
\text { Exxon }\end{array}$ & -65.53 & $0.0127 * * * * *$ & -54.16 & & 33 \\
\hline $\begin{array}{c}\text { Post- } \\
\text { Exxon }\end{array}$ & 82.87 & & -69.00 & $0.0340 * * * * *$ & 37 \\
\hline
\end{tabular}

Note: The data covers the time period from November 1, 2004 to October 31, 2012. $* * * * * \mathrm{p}<0.05$. The significance median difference is based upon a Mann-Whitney test; the significance mean difference is based upon a t-test.

Data Source: Lexis-Nexis Database

Returning to the subject of ratio of punitive to compensatory damages, a statistically significant change has not been observed. As stated above, the ratio is the one that the Court believes to be a pivotal criterion or a guiding principle to decide whether the amount of punitive damages awarded is constitutional. That is the reason why we ought to examine it here.

In this section, the increasing rate means the rate of the latter to the former ratio minus one. As an illustration, if the ratio of pre-Exxon punitive to compensatory

147 See, e.g., Wallace v. DTG Operations, Inc., 563 F.3d 357, 363 (8th Cir. 2009).

148 Eisenberg \& Heise, Judge-Jury Difference, supra note 22, at 348. 
awards is 13.29 and post-Exxon it is 3.57 , the increasing rate equals $1-3.57 / 13.29$ namely, $-73.12 \%$ (decreasing rate: $73.12 \%){ }^{149}$

As shown in Table 10, the median of the increasing rate of ratio seems to have dropped by as much as $17.09 \%$. However, using a Mann-Whitney test, the difference is not statistically significant $(\mathrm{p}=0.2083$ ), which implies that the Exxon decision did not radically affect the decreasing rate of ratio of punitive to compensatory damages for cases involving remittitur.

According to these results, one may say that while Exxon has succeeded in curbing the level of punitive damages to the point where a statistically significant difference has been seen, the ratio is still not within a reasonable range as far as the federal circuit courts are concerned.

In that regard, employing the ratio as a pivotal guiding principle of constitutionality of the punitive awards might be questionable. We will discuss this concept further below.

Table 10: Increasing Rate of Ratio of Punitive to Compensatory Awards, pre/post Exxon (2008) for Cases with Reduction

\begin{tabular}{|c|c|c|c|}
\hline Period & Median (\%) & $\begin{array}{c}\text { Significance of } \\
\text { pre/post Exxon } \\
\text { Difference }\end{array}$ & N \\
\hline Pre-Exxon & -58.73 & 0.2083 & 31 \\
\hline Post-Exxon & -75.82 & 36 \\
\hline
\end{tabular}

Note: The data covers the time period from November 1, 2004 to October 31, 2012. Three cases have been excluded where compensatory damages are zerio (ratio incalculable.) The significance median difference is based upon a MannWhitney test.

Data Source: Lexis-Nexis Database

\section{F. Stratifying the Punitive to Compensatory Ratio}

As pointed out in Section II.E, one of the factors that led the U.S. Supreme Court astray is having grouped the cases with low and high compensatory damages together. That is what Eisenberg and his coauthors correctly clarified by stratifying the level of compensatory awards in the data sets that the Court relied on in Exxon. ${ }^{150}$ In this Section, we explore, using our gathered data, whether or not high compensatory damage cases are different from low ones in the same way as Eisenberg did.

Table 11 shows the result of median, mean, and standard deviation of punitive to compensatory damages ratio, across compensatory award ranges divided into seven layers. It is striking that all three indicators (i.e., median, mean, and standard deviation) decrease as compensatory damages increase. Notably, as for the cases with compensatory awards equal to or more than $\$ 100,000$, the median is quite stable at below 2.00. Likewise, the mean or the standard deviation dramatically falls off, with an exception for the penultimate numerical row of the Table. That is solely because the range includes just one case whose ratio of punitive to compensatory damages is extremely high at as much as $11,417.32 .{ }^{151}$ The numbers in parentheses

149 In re Rountree, 478 F.3d 215, 218 (4th Cir. 2007).

150 Eisenberg et al., Variability in Punitive Damages, supra note 22, at 17-20.

151 Brown v. R.J. Reynolds Tobacco Co., 611 F.3d 1324, 1327 (11th Cir. 2010). 
are those calculated with the exclusion of the outlier. One can see a pattern of decline clearly within these numbers.

The penultimate column in the Table indicates the number of cases with ratios equal to or greater than 10 , showing that only 63 out of 303 cases resulting in a punitive damages award have ratios exceeding a single digit-which the Court suggests will hardly, "to a significant degree[,] . . . satisfy due process" in the State Farm decision. ${ }^{152}$ The column also indicates that the rate of cases with ratios over 10 drops dramatically at the very high levels of compensatory awards granted.

Table 11: Stratifying the Punitive to Compensatory Ratio by Size of the Compensatory Award

\begin{tabular}{|c|c|c|c|c|c|}
\hline $\begin{array}{l}\text { Compensatory } \\
\text { Award Range }\end{array}$ & $\begin{array}{c}\text { Median } \\
\text { Punitive to } \\
\text { Compensatory } \\
\text { Ratio }\end{array}$ & $\begin{array}{c}\text { Mean Punitive } \\
\text { to } \\
\text { Compensatory } \\
\text { Ratio }\end{array}$ & $\begin{array}{c}\text { Punitive to } \\
\text { Compensatory } \\
\text { Ratio } \\
\text { Standard } \\
\text { Deviation }\end{array}$ & $\begin{array}{c}\begin{array}{c}\text { Number } \\
\text { of Cases } \\
\text { with }\end{array} \\
\text { Ratios } \\
\text { Greater } \\
\text { than } \\
\text { Single } \\
\text { Digit }\end{array}$ & $\mathbf{N}$ \\
\hline \$k to 999 & $5,000.00$ & $203,356.89$ & $545,213.79$ & 11 & 13 \\
\hline$\$ 1 \mathrm{k}$ to $\$ 9,999$ & 30.21 & 95.77 & 222.16 & 10 & 14 \\
\hline $\begin{array}{l}\$ 10 \mathrm{k} \text { to } \\
\$ 99,999\end{array}$ & 3.49 & 8.55 & 18.78 & 19 & 74 \\
\hline $\begin{array}{l}\$ 100 k \text { to } \\
\$ 999,999\end{array}$ & 1.63 & 12.59 & 40.16 & 12 & 117 \\
\hline $\begin{array}{c}\$ 1 \mathrm{~m} \text { to } \\
\$ 9,999,999\end{array}$ & 1.51 & 4.89 & 12.98 & 9 & 66 \\
\hline $\begin{array}{c}\$ 10 \mathrm{~m} \text { to } \\
\$ 99,999,999\end{array}$ & 1.00 & $674.27(2.83)$ & $\begin{array}{c}2,768.452 \\
(4.52)\end{array}$ & 2 & $\begin{array}{c}17 \\
(16)\end{array}$ \\
\hline $\begin{array}{l}\$ 100 \mathrm{~m} \text { or } \\
\text { greater }\end{array}$ & 1.00 & 1.00 & 0.00 & 0 & 2 \\
\hline
\end{tabular}

Note: $\mathrm{k}=1000 ; \mathrm{m}=1,000,000$. The data covers the period from November 1 , 2004 to October 31, 2012.

Data Source: Lexis-Nexis Database

From a statistical viewpoint, one can examine the difference of median, mean, and standard deviation across large and small compensatory awards. As Table 12 illustrates, the null hypotheses that median and standard deviation for cases with compensatory awards less than $\$ 10,000$ are the same as those for cases with compensatory awards of $\$ 10,000$ and more have been rejected. In other words, a statistically significant difference within two groups is observed with regard to both the median and standard deviation of ratio $(p<0.001)$, although the mean does not achieve a statistical significance for some reason or another $(\mathrm{p}=0.19)$.

So far, we have seen that the patterns of ratios are so different across ranges that we need to pay close attention to the level of compensatory awards when discussing the constitutionality of the punitive awards. The risk of an underlying inconsistency attends the Court's holding in Exxon, as can be seen in the following quotation:

152 See State Farm Mut. Auto. Ins. v. Campbell, 538 U.S. 408, 425 (2003). 
"[M]aking policy or doctrine based on grouping high and low compensatory cases together is questionable." 153

Table 12: Test of the Hypotheses that Median, Mean, and Standard Deviation for Cases with Compensatory Awards Less than $\$ 10,000$ Equal those for Cases with $\$ 10,000$ or More

\begin{tabular}{|c|c|c|c|c|c|}
\hline $\begin{array}{l}\text { Compensatory } \\
\text { Award Range }\end{array}$ & $\begin{array}{c}\text { Median } \\
\text { Punitive to } \\
\text { Compensatory } \\
\text { Ratio }\end{array}$ & $\begin{array}{c}\text { Mean Punitive } \\
\text { to } \\
\text { Compensatory } \\
\text { Ratio }\end{array}$ & $\begin{array}{c}\text { Punitive } \\
\text { Compensatory } \\
\text { Ratio Standard } \\
\text { Deviation }\end{array}$ & $\begin{array}{c}\text { Number } \\
\text { of Cases } \\
\text { with } \\
\text { Ratios } \\
\text { Greater } \\
\text { than } \\
\text { Single } \\
\text { Digit }\end{array}$ & $\mathbf{N}$ \\
\hline \$1 to 9,999 & 81.30 & $97,962.24$ & $384,587.28$ & 21 & 27 \\
\hline $\begin{array}{c}\$ 10,000 \text { or } \\
\text { greater }\end{array}$ & 1.23 & 50.33 & 687.30 & 42 & 276 \\
\hline
\end{tabular}

Note: The data covers the time period from November 1, 2004 to October 31, 2012. $* *$ Difference between low and high compensatory awards is significant at $\mathrm{p}<0.001$.

\section{G. Federal Circuit Court and Punitive Damages}

In this Section, we focus on federal circuit court judges' decisions regarding punitive damages awards. When reviewing the facts of the case and deciding to affirm or deny (vacate, reverse, and/or remand) the punitive damages awarded by a jury or trial judge, what factors or elements do circuit court judges take into consideration? Answering this question could clarify the relation between the U.S. Supreme Court decisions and those of federal circuit courts.

From the perspectives of the U.S. Supreme Court's doctrines, such as Gore's three-pronged guideline, the single digit rule in State Farm, or the one-to-one rule in Exxon, it seems more likely that the punitive to compensatory ratio, rather than amounts of punitive awards, dominates the reasoning in federal circuit court decisions. Examining this issue is not only rewarding and worthwhile, but also feasible and practical when it comes to adopting a statistical evaluative approach.

\section{Federal Circuit Court Judges' Decisions to Affirm or Deny Awarded Punitive} Damages

Table 13 shows the results of median punitive damages awarded and ratio by decision. Broadly speaking, federal circuit court judges tend to negate, rather than declare valid, more punitive damages awards. Furthermore, as one would naturally predict, the difference between affirmation and denial is highly statistically significant in all medians. It is noteworthy that the most pronounced finding in this Table is the gap of median ratio across decisions. Therefore, it seems plausible that circuit court judges are more likely to negate the punitive damages award in cases where the ratio exceeds three, as opposed to when it falls below three.

However, we cannot conclude that the ratio is the only influential element of the equation that judges consider when reviewing the constitutionality of the award. There is, thus, a need for an additional analytical approach in order to examine a

153 Eisenberg et al., Variability in Punitive Damages, supra note 22, at 20. 
cause-and-effect relationship between a court's decision and factors, such as ratio, amount of the punitive damages award, case category, and so on.

Table 13: Median Punitive Award and Ratio, by Federal Circuit Court's Decisions

\begin{tabular}{|c|c|c|c|c|c|}
\hline Decision & $\begin{array}{c}\text { Median Punitive } \\
\text { Award } \\
\text { (untransformed) }\end{array}$ & $\begin{array}{c}\text { Median } \\
\text { Punitive } \\
\text { Award (log } \\
\mathbf{1 0}\end{array}$ & $\mathbf{N}$ & $\begin{array}{c}\text { Median Ratio } \\
\text { of } \\
\text { Compensatory } \\
\text { Award }\end{array}$ & N \\
\hline Affirmation & 268,000 & 5.4279 & 200 & 1.82 & 189 \\
\hline Denial & $1,006,333^{* * * * * *}$ & $6.0027 * * * * * *$ & 118 & $3.06 * * * * * *$ & 114 \\
\hline
\end{tabular}

Note: The data covers the time period from November 1, 2004 to October 31, 2012. Fifteen cases have been excluded where compensatory damages are zero (ratio incalculable.) The significance median difference is based upon a MannWhitney test. $* * * * * *$ decision difference is significant at $\mathrm{p}<0.01$.

Data Source: Lexis-Nexis Database

2. Logistic Regression Models of Whether or Not Awarded Punitive Damages Were Affirmed

Although we are not privy to the process behind all high courts' holdings, logistic regression models enable us to know judges' overall tendencies when determining the constitutionality of punitive damages awards.

Because the dependent variable in a model of the decision to affirm the awarded punitive damages is dichotomous, we have employed logistic regression models, which are commonly used when analyzing the risk factors in various research fields, including epidemiological surveys. In this study, using logistic regression models helps us understand the degree and significance of each factor's effects on the outcome. ${ }^{154}$

Table 14 reports the results of logistic regression analyses that explore the effects of logged punitive damages awards (log 10), logged ratio of punitive to compensatory awards (log natural), dummied jury trial, party status, and case category. We added elements such as a jury's participation to examine higher court judges' prejudice against fact-finders, a party's status to explore the relationship between defendant's wealth and the decision, and case category to test the link between wrongdoers' reprehensibility and the outcome.

In both Models $1 \& 2$, the coefficient on the punitive damages award variable is considerably large and highly statistically significant. Moreover, the values on each coefficient are all negative, meaning that the more punitive damages awarded, the less likely a higher court is to affirm the amount awarded.

Other factors, including ratio, show no significance, despite our predictions to the contrary. Elements other than the size of the punitive damages award (log 10) have little or no impact on decisions.

To summarize, it is neither ratio nor case category but the amount of punitive damages in its own right that determines the constitutionality of the award. That is, the sum of the punitive damages awarded has the most powerful impact on the high courts' decisions to affirm or negate the award. It is noteworthy that ratio, one of the

154 For an understanding of logistic regression, see generally DAVID W. HOSMER \& Stanley Lemeshow, Applied Logistic Regression (2d ed. 2000). 
most reliable and promising guideposts rendered by the U.S. Supreme Court, is not a statistically significant factor, suggesting that circuit court judges do not rely on the ratio when deciding whether the punitive damages violate the due process of law. ${ }^{155}$ Therefore, we can safely say that U.S. Supreme Court holdings do not function as the key criteria. Instead, circuit court judges do not follow the Court's rationale regarding the ratio of punitive to compensatory damages.

Table 14: Logistic Regression Models of Whether Awarded Punitive Damages Were Affirmed by the Appellate Courts

\begin{tabular}{|c|c|c|}
\hline & Model 1 & Model 2 \\
\hline & Dependent Variable $=$ Punitive Damages Affirmed \\
\hline Punitive Award (log 10) & $-0.3829 * * * * * *$ & $0.4809 * * * * * *$ \\
\hline $\begin{array}{c}\text { Ratio of Punitive to } \\
\text { Compensatory Awards } \\
\text { (log natural) }\end{array}$ & -0.0958 & -0.0810 \\
\hline Jury Trial Dummy & & -0.2790 \\
\hline Party Status & -0.4849 & \\
\hline $\begin{array}{c}\text { Individual v. Non- } \\
\text { Individual }\end{array}$ & -0.0715 & ------- \\
\hline Non-Individual v. Non- \\
individual
\end{tabular}

Note: The data covers the time period from November 1, 2004 to October 31, 2012. Fifteen cases out of 318 have been excluded where the plaintiff won a zero compensatory award (ratio incalculable.) $* * * * * * * p<0.01$.

Data Source: Lexis-Nexis Database

\section{DISCUSSION}

\section{A. Key Findings}

Our current study attempted to examine the impact of U.S. Supreme Court decisions concerning punitive damages on lower courts using 318 federal circuit court decisions. ${ }^{156} \mathrm{We}$ obtained the following five main results.

One key finding is that, as is shown in prior studies, there is no difference between decisions made by juries or judges when assessing damages. Conventional wisdom used to be that juries are so passionate about outrageous conduct by defendants that they frequently tend to award huge punitive damages against large companies; therefore, the jury system is the main culprit of the current tort law crisis. This study confirms the opposite in the way of federal circuit court cases. That is, juries award damages in the same way as judges sitting alone.

A second important finding is the surprising stability of the ratio before and after Philip Morris and Exxon. ${ }^{157}$ Contrary to our prediction, this exploration established

155 See infra Tbl.14.

156 Momioka, Data Set, supra note 110. 
that those two decisions have not changed the proportionality between punitive to compensatory awards. ${ }^{158}$ Given that in most cases the fact-finder is a jury, there is an implication that the juries remain unaffected by U.S. Supreme Court decisions, at least with respect to punitive damages. ${ }^{159}$

A third finding of great interest is about decreasing rates after remittitur of awards granted by trial court judges. A statistical analysis of sixty-seven cases with such a reduction showed that Exxon has succeeded in curving the level of punitive damages awarded but that it has not managed to control the ratio. However, given the fact that remittitur is within a judge's discretion, these findings do not exclude the possibility that judges might have accepted or shared the Court's concerns over "skyrocketing" punitive awards.

A fourth key finding derives from stratifying the compensatory damages. The result is that the ratio becomes low and stable when the amount of compensatory awards is large. That result warns that it is risky and misleading to analyze damages awards together, primarily because the ratios significantly differ in both variance and median.

A fifth main finding was acquired by employing logistic regression models. One can find that proportionality between punitive and compensatory awards is not the key factor that influences federal circuit court judges when deciding the constitutionality of a punitive damages award. Judges consider the amount of punitive damages awarded in their own right rather than employing or utilizing ratios.

\section{B. Implications of This Study}

The above findings require us to consider the meaning and function of a "ratio" again when dealing with punitive damages awards. We discuss here whether it is appropriate for the Court to employ ratio analysis of punitive to compensatory damages as a crucial factor in appellate court review regarding the constitutionality of such awards. From an empirical or statistical perspective, is the ratio still a useful and effective factor? If not, is there a promising alternative?

To answer these questions, it is very helpful for us to rely upon stratification of damage awards. As shown in Section III.F and Table 11, the ratio and its variation differences between small and large compensatory damages zones are so significant that using a ratio calculated by taking into account the whole data is completely misleading. That is the very point where the analysis breaks down.

157 Id.

158 Id.

159 For the link between the Supreme Court decisions and social changes in general, see Gerald N. Rosenberg, The Hollow Hope (2d ed. 2008). Rosenberg argues that even the Court's Brown v. Board of Education decision in 1954, often cited as a milestone of the Civil Rights Movement, had quite a limited impact on American society. Id. at 156 ("While it must be the case that Court action influenced some people, I have found no evidence that this influence was widespread or of much importance to the battle for civil rights"); see also Herbert M. Kritzer, The Impact of Bush v. Gore on Public Perceptions and Knowledge of the Supreme Court, 85 JudiCATURE 32, 34 (2001) ("[T] he public knows little about the Court and its workings."). For a more general discussion of law and social change, see Scott L. Cummings, Empirical Studies of Law and Social Change: What is the Field? What are the Questions?, 2013 WIS L. REV. 171, 173 (2013). 
Thus, one possible solution to this problem is that the Court suggests handling punitive damages cases separately by dividing the compensatory awards into several parts and setting a ratio for each zone. This proposal, however, rests on the premise that utilizing a ratio is an effective approach.

On the other hand, it is true that judges and juries utilize ratio analysis differently. As shown in Sections III.E.2-3, while no statistically significant change before and after Exxon has been observed in the ratios of punitive to compensatory damages awarded mainly by juries, ${ }^{160}$ the rate at which punitive damages were reduced by trial court judges showed a significant rise after Exxon. ${ }^{161}$ This difference ultimately derives from each adjudicator's position and capacity-judges hate to have their decisions reversed or vacated by upper court judges and tend to hew to the U.S. Supreme Court's holdings because of their professional and reputational interest. Jurors, however, do not have to obey the case law doctrine, such as the "one-to-one ratio rule" declared in Exxon or the "third party rule" in Philip Morris, unless they are told to do so by the presiding district court judge. ${ }^{162}$ In that regard, one could say that judge-jury difference in responding toward the Court's holdings is all too clear in the results of this study.

However, the relationship between adjudicator selection by litigants and the level of the ratios still needs further exploration. Literally, the jury is still out on this question.

\section{Limits of the Present Study}

Finally, it is of great importance to state what this article does not necessarily suggest, as well as some notable limitations.

First, this study is intended to be exploratory with a limited sample of data from appellate court decisions compromised of only 318 punitive damages cases, which is not sufficient for data analysis. Furthermore, we cannot totally exclude the possibility that the gathered data is "selective" or distorted precisely because the source is a commercial database, LexisNexis. These weaknesses should be improved in the next research.

Another limitation of this study, which should be addressed in the future, is the unexplained relationship between the amount of punitive damages awarded and the wealth of defendants. Although the U.S. Supreme Court acknowledged the importance of this issue, it has not made clear whether or not it is permissible for a fact-finder to take into consideration the wealth of a defendant when assessing punitive damages, and if so, to what extent. The Court will likely have to make a decision on this point in the near future.

These issues, however, need to be discussed separately in future research.

\section{CONCLUSION}

It follows from what has been said thus far that the overall trend of the size of punitive damages awarded has been quite stable over time and not affected by U.S. Supreme Court decisions such as Philip Morris or Exxon.

160 See supra Tbl.8

161 See supra Tbl.9

162 See, e.g., Eisenberg \& Heise, Judge-Jury Difference, supra note 22, at 348 (discussing difference in judge-jury behavior in U.S. Supreme Court decisions). 
Finally, it should be pointed out that disobedience of the federal circuit courts to the U.S. Supreme Court decisions, with regard to punitive damages awards, does not necessarily suggest their dysfunction in American society. On the contrary, the significant stability in the level of punitive damages awarded and ratios of the last eight years may indicate that the punitive damages regime continuously serves the social justice purpose of letting the victims of big corporations achieve vindication through civil lawsuits. This is exactly the raison d'être punitive damages, which continues to intrigue foreign jurists like us in Japan, because it achieves law enforcement by private parties, not by bureaucratic order or legislation.

In conclusion, this article contributes to growing literature suggesting the importance of employing statistical analyses in understanding myth and reality with regard to punitive damages awards. 